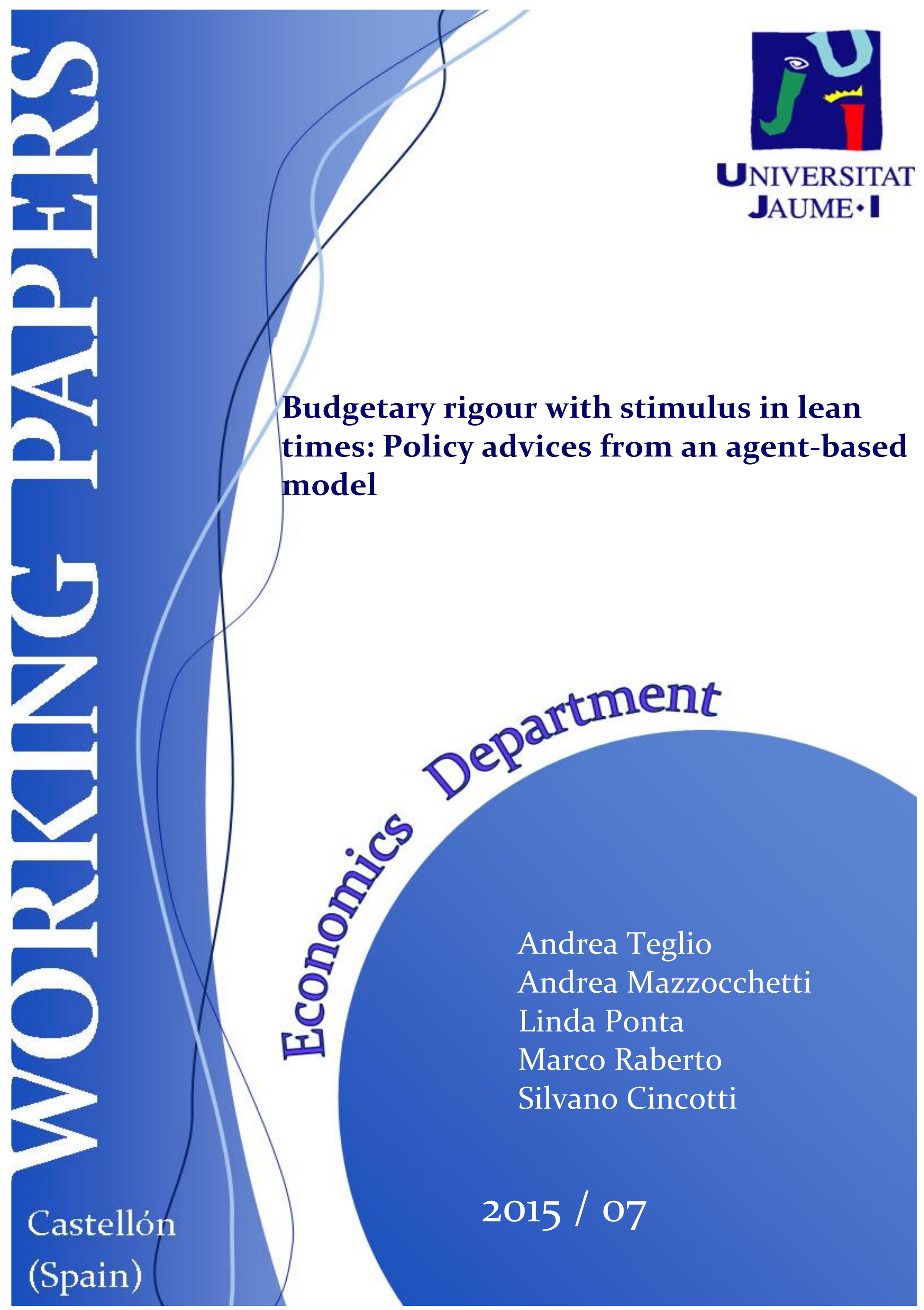




\title{
Budgetary rigour with stimulus in lean times: Policy advices from an agent-based model
}

\author{
Andrea Teglio \\ Universitat Jaume I \\ Department of Economics \\ teglio@uji.es
}

\author{
Andrea Mazzocchetti \\ Università di Genova \\ DIME-CINEF \\ Andrea.mazzocchetti@edu.unige.it
}

\author{
Linda Ponta \\ Università di Genova \\ DIME-CINEF \\ linda.ponta@unige.it
}

\author{
Marco Raberto \\ Università di Genova \\ DIME-CINEF \\ marco.raberto@unige.it
}

\author{
Silvano Cincotti \\ Università di Genova \\ DIME-CINEF \\ silvano.cincotti@unige.it
}

\begin{abstract}
2015 / 07
Abstract

The 2008 financial crisis, and the subsequent global recession, triggered a widespread economic and political debate on the proper policy combination to deal with the crisis and to prevent similar ones in the future. Probably, the main dispute has been around the use of fiscal instruments in order to foster growth while keeping public debt under control. The European Union, for instance, endorsed measures for fiscal consolidation but has been sharply criticized by several scholars as well as Nobel Laureates. This paper aims at contributing to this debate by presenting the outcomes of a computational study performed with the Eurace agent-based model. We set up an experiment with two base policy scenarios, i.e., stability and growth pact and fiscal compact, incrementally enriching them with complementary policies which relax fiscal rigidity and introduce quantitative easing. We are therefore able to compare eight policy combinations, spanning different degrees of fiscal and monetary expansion. Results show that budgetary rigour performs well if and only if some mechanisms of fiscal relaxation and monetary accommodation are considered during bad times; thus confirming in a richer and more realistic model setting the fundamental tenet of Keynesian economics about the importance of sustaining aggregate demand during recessions.
\end{abstract}

Keywords: fiscal policy, quantitative easing, financial stability, economic crisis, agent-based modelling

JEL classification: E63, G01, H12, C63 


\title{
Budgetary rigour with stimulus in lean times: policy advices from an agent-based model
}

\author{
Andrea Teglio ${ }^{\mathrm{a}, 1}$, Andrea Mazzocchetti ${ }^{\mathrm{b}}$, Linda Ponta ${ }^{\mathrm{b}}$, \\ Marco Raberto ${ }^{\mathrm{b}}$, Silvano Cincotti ${ }^{\mathrm{b}}$ \\ ${ }^{a}$ Universitat Jaume I, Campus del Riu Sec, 12071 Castellon, Spain \\ ${ }^{\mathrm{b}}$ DIME-CINEF, Università di Genova, Via Opera Pia 15, 16145 Genova, Italy
}

\begin{abstract}
The 2008 financial crisis, and the subsequent global recession, triggered a widespread economic and political debate on the proper policy combination to deal with the crisis and to prevent similar ones in the future. Probably, the main dispute has been around the use of fiscal instruments in order to foster growth while keeping public debt under control. The European Union, for instance, endorsed measures for fiscal consolidation but has been sharply criticized by several scholars as well as Nobel Laureates. This paper aims at contributing to this debate by presenting the outcomes of a computational study performed with the Eurace agent-based model. We set up an experiment with two base policy scenarios, i.e., stability and growth pact and fiscal compact, incrementally enriching them with complementary policies which relax fiscal rigidity and introduce quantitative easing. We are therefore able to compare eight policy combinations, spanning different degrees of fiscal and monetary expansion. Results show that budgetary rigour performs well if and only if some mechanisms of fiscal relaxation and monetary accommodation are considered during bad times; thus confirming in a richer and more realistic model setting the fundamental tenet of Keynesian economics about the importance of sustaining aggregate demand during recessions.
\end{abstract}

Key words: fiscal policy, quantitative easing, financial stability, economic crisis, agent-based modelling

JEL classification: E63, G01, H12, C63

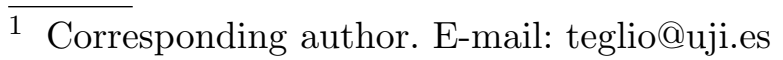




\section{Introduction}

Following the 2008/2009 financial and economic crisis and the consequent bailout of important financial institutions, most OECD countries experienced large deficits and a significant increase of public debt. The 2010 recovery induced policy makers, in particular in the European monetary Union where the room of manoeuvre of fiscal policy is conditioned by treaties, to shift the attention from the financial crisis and its causes to the need of fiscal consolidation measures aimed to put public finances on a more "sustainable" path. In the political and theoretical debate, it became popular the assumption that fiscal consolidation could be very successful in reducing public deficit, in particular due to its claimed expansionary effects. The so-called expansionary austerity hypothesis was supported by both empirical analysis, see e.g. Alesina and Ardagna (2010) and references therein, and theoretical arguments. Under the theoretical perspective, fiscal austerity might have expansionary effects because, if we assume forward-looking economic agents, todays sacrifices may create expectations of tax reductions, higher disposable income, and lower interest rates ${ }^{1}$ in the future, then inducing agents to increase consumption and investment in the short term.

However, economies subject to austerity programs experienced a second severe contraction of economic activity soon after 2010; in addition, bond yields of peripheral Euro-zone countries, skyrocketed to unsustainable levels in 2011. Indeed, beside the literature supporting expansionary austerity, a huge body of both theoretical and empirical work advocating the contrary exists, dating back at least to Keynes' General Theory (1936) and Lerner's functional finance (Lerner and Harris, 1951). In particular, in recent years, in response to the 2008/09 crisis, a number of studies have appeared emphasizing the importance of expansionary fiscal policy during recessions. DeLong and Summers (2012) provide theoretical and empirical evidence about the efficacy of temporary expansionary fiscal policy in severely depressed economies, in both the short and the long term. The argumentation is that the underemployment of production factors as well as low interest rates make the fiscal multiplier substantially greater than in normal times, as also pointed out by Auerbach and Gorodnichenko (2012) and Ferraresi et al. (2014). Furthermore, mitigating present output drops, by means of expansionary fiscal policies, prevents the long-term hysteresis effects of the lower capital accumulation rate and workers' skills on the economys future potential.

A new term, balance-sheet recession, has also been coined to define the 2008/09 crisis as well as the Japan two last decades of the 90s and 00s (Koo, 2009, 2011,

$\overline{1}$ A related common justification of austerity programs was the risk that bond
markets, whenever a government is not sufficiently committed to budget balance,
may demand huge spreads for sovereign debt and possibly push a nation into default. 
2014). A balance-sheet recession is the economic crisis that usually follows an asset bubble burst. In this scenario, where the market value of assets collapses while the nominal value of debt remains unchanged, the private sector (households, firms) becomes over-indebted and faces the risk of negative net worth; therefore deleveraging, more than profit maximization, becomes the priority of the private sector, which uses its cash flows to reduce indebtedness instead of financing investments. This deleveraging priority makes also the private sector unwilling to borrow, even at very low interest rates, with financial institutions that are also unwilling to lend, because they need to reduce the risk of their balance sheets. In such a scenario, where private consumption and investment demand decrease, it is therefore argued that the public sector should actually move in the opposite direction, i.e., perform a fiscal stimulus, which would be easily financed due to the excess saving and the low interest rates, with the aim to sustain businesses and households cash flows and to easy balance sheets repair without forcing the economy into depression.

Guajardo et al. (2011), using a different estimation method with respect to the one used by Alesina and Ardagna (2010), find empirical evidence that fiscal consolidation has actually contractionary effects on private domestic demand and GDP, in contrast to the estimates made by Alesina and Ardagna (2010), which the authors show to be biased toward overstating expansionary effects. De Grauwe and Ji (2012) find evidence that a large part of the surge in the spreads of the peripheral Eurozone countries during 2010/11 was disconnected from fiscal fundamentals and was actually the result of time dependent negative market sentiments caused by the particular situation of government bond markets in a monetary union, where countries, being without their own currency, can be subject to self-fulfilling liquidity crises, which instead are ruled out in countries with full monetary sovereignty. Furthermore, if a country in such a scenario is forced into austerity with the aim to reduce bond spreads, high interest rates, impossibility to devaluate the currency, and fiscal consolidation, may cause a deep recession and transform a liquidity crisis in a solvency crisis.

Depending on the economic conditions and on the institutional setting, fiscal austerity may then turn out to be depressive and self-defeating while fiscal stimulus could actually turn out to be expansionary and self-financing. Several scholars, like Nobel laureates P. Krugman and S. Stiglitz ${ }^{2}$, suggested the use of expansionary fiscal policies along with monetary accommodation in order to fight the crisis Krugman (2013).

The political implications of this academic debate are of course of the utmost importance. Mario Draghi, president of the ECB, gave emphasis to fiscal pol-

$\overline{2}$ There are many articles around. See for example Stiglitz's "Agenda to save the Euro" and Krugman's "The Depressed Economy Is All About Austerity" http://krugman.blogs.nytimes.com/2013/09/24/the-depressed-economy-is-allabout-austerity/ 
icy in his recent speech ${ }^{3}$ at the annual central bank symposium in Jackson Hole, on 22 August 2014. Apart from the needed caution, requested by his office, what clearly emerges from the speech of Mario Draghi is the need for a more active and expansionary fiscal policy, alongside monetary policy. Draghi suggests a "more growth friendly composition of fiscal policies" stating that "as a start, it should be possible to lower the tax burden in a budget-neutral way". Draghi's speech was centered on responding to the high unemployment rates which grip many countries of the EU. In his vision, aggregate demand policies are an essential piece in order to take the route which leads out of the crisis.

Coherently, the ECB president launched an expanded asset purchase programme at the beginning of $2015^{4}$, stating that "domestic demand should also be further supported by our monetary policy measures" and suggesting that "fiscal policies should support the economic recovery, while ensuring debt sustainability in compliance with the Stability and Growth Pact, which remains the anchor for confidence. All countries should use the available scope for a more growth-friendly composition of fiscal policies".

However, Draghi's moderate vision about combining growth friendly fiscal policies with an accommodative monetary policy has not always been shared by other central bankers, and a political and economic debate flourished in the last years. Dr Jens Weidmann, the current president of the Deutsche Bundesbank, gave recently a speech ${ }^{5}$ at the École des Hautes Études Commerciales in Paris, with a self explaining title: "Fiscal and Monetary Policy - Dancing too Close?". Weidmann's answer is yes and he states that "if we care about stable prices and if we care about purchasing power then we should be worried. We should be worried because on the European dance floor monetary and fiscal policy are moving toward each other".

Based on the current academic and political discussion, we design several fiscal policy strategies (possibly accompanied by monetary accommodation) to be tested and compared in the framework of an enriched version of the agentbased Eurace model (Cincotti et al., 2010, 2012a,b; Raberto et al., 2012; Teglio et al., 2012). The main idea is to ground our study on the current political and economic debate, proposing different scenarios which could be valuable to policy makers. Moreover, we want to analyze mainly scenarios of economic crisis, in order to embed our study into the recent past.

3 Unemployment in the euro area. Speech by Mario Draghi, President of the ECB, Annual central bank symposium in Jackson Hole, 22 August 2014. http://www.ecb.europa.eu/press/key/date/2014/html/sp140822.en.html

4 Mario Draghi, President of the ECB, Frankfurt am Main, 22 January 2015. https://www.ecb.europa.eu/press/pressconf/2015/html/is150122.en.html

5 http://www.bundesbank.de/Redaktion/EN/Reden/2013/2013_02_25_weidmann_ paris.html 
For this purpose, we argue that the agent-based approach (see e.g. Tesfatsion and Judd (2006); LeBaron and Tesfatsion (2008)) has some advantage with respect to mainstream approaches in macroeconomics based on dynamic stochastic general equilibrium models. It allows for more realistic agents behaviour, based on heuristics and behavioural patterns, see e.g. Akerlof (2002)), instead of perfect rationality, and it also allows for non-clearing and decentralized markets Raberto et al. (2008a). Furthermore, agent-based modelling allows for richer economic scenarios, where out-of-equilibrium aggregate outcomes emerge from the complex pattern of agents' interaction and not just as the results of equilibrium conditions in Walrasian centralized markets with representative agents (Colander et al., 2008; Kirman, 1992), then subject to fallacies of composition like the well-known Keynesian paradox of thrift.

Among the relatively small number of agent-based macro-models in circulation, see e.g. Ashraf et al. (2014); Delli Gatti et al. (2011); Gabbi et al. (2015); Gualdi et al. (2015); Rengs and Wackerle (2014); Riccetti et al. (2013); Wackerle et al. (2014), it is worth citing the Keynesian model by (Dosi et al., 2010), which has been recently used to test different fiscal and monetary policy scenarios (Dosi et al., 2013, 2015). Results show that the introduction of constrained fiscal rules mimicking the Stability and Growth Pact or the Fiscal Compact worsen the performance of the economy as well as public finances, while the best policy mix able to stabilized macroeconomic fundamentals is the combination of an unconstrained fiscal policy with a dual-mandate monetary policy, targeting both inflation and unemployment. Among other agent-based studies on the recent crisis, Assenza et al. (2015) focus on the emergence of a crisis from micro behavioral interactions, while Klimek et al. (2015) focus on crisis resolution mechanisms, finding that there are no economic conditions under which a taxpayer-funded bail-out outperforms the bail-in mechanism with private sector involvement.

In order to investigate the effects of different fiscal policies, we design simulations which diverge only on the edge of a crisis. The idea is to have a common trajectory until a crisis occurs and therefore to switch-on the different policy cases. It is worth noting that, as shown in Raberto et al. (2012) and Cincotti et al. (2012b), the Eurace model is able to reproduce endogenous business cycles with recessions of different duration and severity. We also observe that recessions which are most severe are usually the consequence of endogenous boom and bust credit-driven cycles, with strong similarity with the 2008/09 financial crisis. Our setting provides the opportunity to compare, ceteris paribus, how different policies can affect the development of a crisis, measuring some key indicators like the average duration of the crisis, average unemployment, inflation or GDP, among others.

Let us finally spend a few words on the methodology of large-scale agent-based models. In our opinion, there is an important trade off between the analytical 
tractability of a model and the realistic and valuable representation of the economic dynamics. Analytical tractability allows for an easier understanding of the causality chain but often disregards critical elements in the model design (e.g., a financial sector, agents heterogeneity, or defaulting firms). Large scale economic models are able to incorporate many of the relevant features of the economy but can be criticized as a black boxes that produce highly arbitrary results. We are aware of the current limits of the approach and of the skepticism in some areas of the academic community. We are also aware that we have a lot of work in front of us in order to improve the validation procedures of the model. However, both the systematic and rigorous model design and the realism of produced results show that the model, and in general the agent-based approach, is a valuable instrument for the understanding of the economic dynamics of modern economies.

The paper is divided as follows: in the next section we present an overview of the Eurace model, while the technical details are provided in the Appendix. Section 3 describes the proposed fiscal and monetary policy scenarios, while results of computational experiments are discussed in Section 4. Finally, we draw our main conclusions in section 5 .

\section{Overview of the Eurace model}

Eurace is an agent-based macroeconomic model and simulator which is under development since 2006. Eurace agent population is characterized by different types of agents: households, which act as workers, consumers and financial investors; consumption goods producers (CGPs), henceforth firms, producing a homogenous consumption goods; a capital goods producer; commercial banks and two policy makers agents, namely a government and a central bank, which are in charge of fiscal and monetary policy, respectively.

Agents interact through different markets where consumption and capital goods, labor and credit are exchanged in a decentralized setting with disperse prices set by suppliers and based on costs. Agents' behavior is modelled as myopic and characterized by limited information, scarce computational capabilities and adaptive expectations. For instance, CGPs are characterized by a short-term profit objective and make production and investment plans where expected future revenues are based on backward-looking expectations determined by past sales and prices. In particular, production plans depend on past sales and the inventory stock, along the lines of the inventory management literature (Hillier and Lieberman, 1986), while sale prices are determined by a mark-up on costs (wages and debt interests), see. e.g. Plott and Sunder (1982); Fabiani et al. (2006). Investment plans depend on the cost of capital 
goods and the present value ${ }^{6}$ of the additional foreseen revenues, but are limited by both by internal ${ }^{7}$ and external financing capabilities ${ }^{8}$.

Households set the consumption budget out of their income following a wealth to income target ratio, according to the theory of buffer-stock saving Carroll (2001); Deaton (1992), which states that consumption expenses mainly depend on the need to accumulate a target stock of liquid wealth to be used as a buffer in cases of income downfalls, due to e.g. unemployment. Savings can be allocated in stocks (i.e. the claims on firms/banks equity and future dividends) and government bonds, which are traded in a centralized Walrasian financial market.

Banks have the function to provide short-term loans to firms at an interest rate determined by the cost of central bank loans, i.e. the policy rate, plus a markup. It is worth noting that, in line with the working of the banking system in a modern capitalist economy (see e.g. McLeay et al. (2014)), banks lending is not limited by the available liquidity and, whenever a bank grants a loan, a corresponding deposit, entitled to the borrower, is created on the liability side of the bank' balance sheet. Furthermore, if it happens that a bank becomes short of liquidity after the settlements of all payments of its clients (households, firms, the capital good producer), the the bank gets a loans from the central bank which can provide liquidity to the banking system in infinite supply. In line with the post-Keynesian literature, see e.g. Fontana (2003); Lavoie and Godley (2012), we then follow the endogenous money modelling approach, where loans come before deposits, not viceversa as in standard textbooks, and, whenever the private sector is willing to borrow more money, banks normally provide more loans and then create endogenously more banking deposits, i.e., new money. Bank lending is however limited by a Basel II-like capital requirement rule; in this respect, each bank assesses the loan risk by considering the financial leverage of the prospective borrower before deciding about a loan request.

Finally, a distinctive feature of the Eurace modelling approach is that every agents is modelled through a double-entry balance sheet that includes the details of all assets and liabilities. Agent types' balance sheets along with balance sheets entries and related symbols are reported in Table 8, while agents' decision making and interactions through the different market settings are described in the Appendix. Balance sheet entries can be regarded as the state variables of any agent and the state of the Eurace economy can be described as the whole set of the balance sheet variables of any agent.

The dynamical change of balance sheet variables depend on agents' plan and on the result of agents interaction within the different market settings. This

\footnotetext{
6 According to empirical surveys (Graham and Harvey, 2001, 2002), the net present value is one of the most popular method used by managers to evaluate investments. 7 Along the lines of (Fazzari et al., 2008).

8 The pecking order theory (Myers and Majluf, 1984) is adopted to determine a hierarchy of financial sources for the firm
} 
approach allows to check the consistency at any time step between stocks and flows in the model, both at the level of the single agent and at the aggregate one, in line also with post-Keynesian stock-flow-consistent modelling approach, see e.g. Caverzasi and Godin (2015). We believe that this is a critical feature in particular in a model where the creation/desctruction of the endogenous money stock plays a crucial role in determining economic activity.

\section{$3 \quad$ Fiscal and monetary policy scenarios}

We consider 8 combined fiscal and monetary policy scenarios, which can be grouped into 2 main sets, each characterized by 4 policies, i.e., a baseline policy scenario plus three additional nested specifications. The two baseline policy scenarios are named fiscal compact (FC) and stability and growth pact (SGP), respectively. The two names refer to the two well-known European treaties ${ }^{9}$ designed to ensure that countries in the European Union pursue sound public finances and coordinate their fiscal policies. The reason of these two names is because the two baseline fiscal and monetary policies implemented in the Eurace model recall the key elements addressed by the corresponding European agreements. In particular, the SGP policy scenario sets the public deficit ro GDP ratio as the fundamental policy target, while the FC policy scenario addresses the level of the public debt to GDP ratio. In both cases, tax rates on labor and capital income, corporate earnings as well as the value added tax are the policy instruments considered to get the two targets within pre-determined limits.

For each baseline policy scenario, three further nested policy specifications are then considered in order to address economic crises, defined here as periods when the unemployment rate is higher than a given threshold. These further policy specifications, if selected, are effective during periods of crisis, i.e. high unemployment, irrespectively from the deficit and debt to GDP levels. The three new policy specifications are named as: unemployment escape clause $(\mathrm{U})$, which rules out tax hikes; quantitative easing (QE), consisting in the purchase of government bonds by the central bank in the secondary market; fiscal accommodation (FA), where tax rates are lowered on a monthly basis.

The three different policy specifications outlined above are characterized by increasing strength in counteracting the two baseline scenarios in times of high

\footnotetext{
${ }^{9}$ It is worth noting that the Stability and Growth Pact, born in 1997 and later amended, is embodied in the European law, while the Fiscal Compact is an intergovernmental treaty, signed in 2012 by 25 EU member states, which introduces a new stricter version of the Stability and Growth Pact.
} 


\begin{tabular}{|c|c|c|}
\hline Agent & Assets & Liabilities \\
\hline $\begin{array}{l}\text { Household } \\
\text { abbrev.: Hous } \\
\text { index: } h=1, \ldots, N_{\text {Hous }}\end{array}$ & $\begin{array}{l}\text { - Liquidity: } M_{h} \\
\text { - Stock portfolio: } \\
\Sigma_{b} n_{E_{h, b}} p_{E_{b}}+ \\
\Sigma_{f} n_{E_{h, f}} p_{E_{f}}+n_{E_{h, K}} p_{E_{K}} \\
\text { - Gov Bonds: } n_{h, G} p_{G}\end{array}$ & - Equity: $E_{h}$ \\
\hline $\begin{array}{l}\text { Consumption Goods } \\
\text { Producer (firm) } \\
\text { abbrev.: CGP } \\
\text { index: } f=1, \ldots, N_{\text {Firm }}\end{array}$ & $\begin{array}{l}\text { - Liquidity: } M_{f} \\
\text { - Capital goods: } K_{f} \\
\text { - Inventories: } I_{f}\end{array}$ & $\begin{array}{l}\text { - Debt: } D_{f}=\sum_{b} \ell_{f, b} \\
\text { - Equity: } E_{f}\end{array}$ \\
\hline $\begin{array}{l}\text { Capital Goods Pro- } \\
\text { ducer } \\
\text { abbrev: KGP } \\
\text { index: } K\end{array}$ & - Liquidity: $M_{k}$ & - Equity: $E_{k}$ \\
\hline $\begin{array}{l}\text { Bank } \\
\text { index: } b=1, \ldots, N_{\text {Bank }}\end{array}$ & $\begin{array}{l}\text { - Liquidity: } M_{b} \\
\text { - Loans: } \mathcal{L}_{b}=\sum_{f} \ell_{b, f}\end{array}$ & $\begin{array}{l}\text { - Deposits: } \\
\mathcal{D}_{b}=\sum_{h} M_{b, h}+\sum_{f} M_{b, f}+ \\
M_{b, K} \\
\text { - Standing facility with the cen- } \\
\text { tral bank: } \ell_{b, C B} \\
\text { - Equity: } E_{b}\end{array}$ \\
\hline $\begin{array}{l}\text { Government } \\
\text { abbrev.: Gov } \\
\text { index: } G\end{array}$ & - Liquidity: $M_{G}$ & $\begin{array}{l}\text { - Outstanding government } \\
\text { Bonds value: } n_{G} p_{G} \\
\text { - Equity: } E_{G}\end{array}$ \\
\hline $\begin{array}{l}\text { Central Bank } \\
\text { abbrev.: CB } \\
\text { index: } C B\end{array}$ & $\begin{array}{l}\text { - Liquidity: } M_{C B} \\
\text { - Loans to banks: } \\
\mathcal{L}_{C B}=\sum_{b} \ell_{C B, b} \\
\text { - Gov Bonds: } n_{C B, G} p_{G}\end{array}$ & $\begin{array}{l}\text { - Outstanding fiat money: } \\
M_{C B} \\
\text { - Deposits: } \\
\mathcal{D}_{C B}=\sum_{b} M_{C B, b}+M_{C B, G} \\
\text { - Equity: } E_{C B}\end{array}$ \\
\hline
\end{tabular}

Table 1. Balance sheets of agents populating the Eurace economy. Balance sheet entries in the table have a subscript character, that is the index of the agent to which the variable refers. In some cases, we can find two subscript characters, where the second one refers to the index of the agents representing the balance sheets counterparts. For instance, $D_{f}$ refers to the total loans of firm $f$, i.e. a liability, and $\mathcal{L}_{b}$ refers to the total loans of bank $b$, i.e. an asset. $\ell_{f, b}\left(\right.$ or $\ell_{b, f}$ ) refer to the loans issued by banks $b$ to firms $f$. Of course $\sum_{b} \mathcal{L}_{b}$ and $\sum_{f} D_{f}$ represent a balance sheet identity, that is verified along the entire simulation. $n_{E_{h, x}}$ represent the number of outstanding equity shares of agents $x$ held by households $h$. The market price of the equity shares is given by $p_{E_{x}}$. The stock portfolio's value of household $h$ is then computed as: $\sum_{x} n_{E_{h, x}} p_{E_{x}}$. Government bonds' number and market price are given by $n_{G}$ and $p_{G}$, respectively. 
unemployment. First of all, the first choice would be the adoption of the policy measure U, avoiding an increase of tax rates even if deficit or debt to GDP ratios are above their thresholds; in addition to this, the policy maker could also pursue unconventional monetary policy measures (QE) with the aim to sustain bond price and then facilitate government debt financing in times of decreasing fiscal revenues; finally, the previous two policies can be complemented by a fiscal accommodation (FA) where tax rates are quickly (on a monthly basis) lowered to increase the purchasing power of the private sector. Given their particular design, the three policies measures are not applied independently to the two baseline scenarios, but are taken into consideration following the particular order of adoption previously outlined and given by their different and increasing impact.

Results related to the two baseline policy scenarios, SGP and FC, as well as the additional specifications, will be presented and discussed. In particular, for both baseline cases, we will then have 3 additional policy scenarios. In the SGP case, they will be named as SGP + U, SGP + U + QE, and SGP + U $+\mathrm{QE}+\mathrm{FA}$. We will have analogues scenario names in the FC case.

In the following, we provide the details about the implementation of the two baseline monetary and fiscal policy scenarios:

Stability and Growth Pact (SGP)

SGP scenario targets a level of yearly deficit to GDP ratio equal to 3 percent. At the beginning of every year, government sets concurrently the level of corporate tax, Value-added tax and labour tax according to the current level of deficit to GDP ratio. Three cases are possible:

(1) If the ratio is higher than 3 percent tax rates are increased by 5 percent.

(2) If the ratio is negative, i.e. government incomes are higher than expenditures, tax rates are decreased by 5 percent.

(3) If the ratio is included between 0 and 3 percent, tax rates remain unchanged.

Fiscal Compact $(F C)$

The policy target set in FC scenario is given by a level of debt to GDP ratio equal to 60 percent. At the beginning of every year, government computes the ratio between debt, that corresponds to the value of the outstanding bonds, and GDP. Depending on the level of debt to GDP ratio compared to the target, two main cases are possible: 
(1) If debt to GDP ratio is lower than 60 percent, tax rates are set according to the following rule:

- If deficit to GDP ratio is greater than 0 , tax rates are increased by 5 percent.

- If deficit to GDP ratio is lower than 0 , tax rates are decreased by 5 percent.

(2) If debt to GDP ratio is higher than 60 percent, government computes the twentieth part of the value exceeding the threshold, i.e.

$$
E T=\frac{(D e b t / G D P)-0.6}{20}
$$

In terms of fiscal policy, the effects are twofold:

- Tax rates are increased by 5 percent if the deficit to GDP ratio is greater than ET and decreased otherwise.

- Goverment repurchase bonds in the secondary market for a value equal to $E T$ if its payment account is positive.

In the following, we provide the details about the implementation of the three additional policy specifications:

Unemployment escape clause (U)

At beginning of the year, if the average unemployment rate of the previous year or the current unemployment rate is greater than 10 percent, unemployment escape clause is activated and tax rates are left unchanged despite the level of deficit to GDP ratio and the debt to GDP ratio in SGP and FC basis scenarios, respectively.

Quantitative easing (QE)

Quantitative easing is activated monthly if the current unemployment rate is higher than 10 percent. The unconventional monetary policy consists in the repurchase of government bonds in the secondary market by the central bank. The quantity of bonds to repurchase is set as:

$$
\frac{n_{G} / 10}{240}
$$

Therefore the quantity repurchased is the 10 percent of the outstanding bonds. The quantity is computed on daily basis, being 240 the number of days in a year. The reason is that, even though quantitative easing activation is monthly, central bank enters in the bonds market on a daily basis, in order to smooth the purchase accross the activation period. 
Fiscal accommodation (FA)

Fiscal accomodation is activated on a monthly basis, if the current unemployment rate exceeds the threshold of 10 percent. Being a monthly policy, tax rates decreases are computed as the twelfth part of the yearly tax rates changes, set to 5 percent.

\section{Simulation Results}

One of the most relevant features of the Eurace model is the emergence of endogenous crises, depending on boom-bust credit cycles and the ensuing business cycles. The mechanisms of generation and propagation of such crises have been discussed in previous papers, see e.g. Cincotti et al. (2010); Raberto et al. (2012) or Teglio et al. (2012), and we will recall them in the next section. The results we are going to present here aim at pointing out the effectiveness of the different fiscal and monetary policies, outlined in Sec 3, in preventing or mitigating the endogenous economic crises arising in the Eurace model.

The methodology of our study is based on Monte Carlo computational experiments, consisting in running simulations with different seeds of the pseudorandom number generator for each policy scenario. We consider eight policy scenarios, as explained in section 3, and fifty seeds per scenario, for a total of four hundred simulations. Simulations are performed ceteris paribus, meaning that all the parameters of the economic system are identical across the different policy scenarios, with the exception of the specific parameters characterizing the policy rule of a specific scenario. Simulations run for a time span of twenty five years but they are indistinguishable during the first nine years, when every case runs under the Stability and Growth Pact policy scenario (SGP). Simulations are allowed to diverge at the beginning of year nine, when the distinctions among the different policies are activated. In this way, simulations have a common transition phase, which we discard in the analysis, and a second differentiated period that originates from the same initial conditions. Therefore, given any seed, every divergence among simulated time series is caused by the different fiscal policy choice.

The presentation of results is organized to show both the performance of the different policies during crisis periods and the overall performance of each policy during the entire time span. On the one hand, we focus the attention on what happens during a crisis and why some policies perform better than others; on the other hand, we want to show the behavior of some crucial variables (e.g., public budget related variables) in the long run. 
Simulations have been performed with the following settings: 5,000 Households, 100 Consumption Goods Producers, 5 Banks, 1 Capital Good Producer, 1 Government and 1 Central Bank.

The initialization of a large scale macroeconomic simulator is a complex problem both under the economic and the computational perspective. One has to initialize a set of variables, mostly balance sheet variables, for each agent, with a population of thousand agents, paying attention both to the economic rationale and to consistency requirements among balance sheets. For instance, the sum of all firms' debt liabilities should be equal to the sum of all loans on banks' balance sheet. These types of constraints reduce the degrees of freedom of the problem, but the arbitrariness of many initialization choices is still high. Our approach has been to make a set of ad hoc but sensible assumptions, which are based on realistic ratios among balance sheet entries and stocks versus flows. These assumptions further reduce the degrees of freedom and then allows for an initialization algorithm that, starting from our arbitrary choice of a minimum set of values, automatically set all the initial stock and flow entries necessary for agents's decision making during the first simulation step and also guarantees balance sheets consistency. In practical terms, we set the initial value of the nominal monthly wage of households, and we use it as a unit of measure for all the other variables. For example, from household's wage we derive his total initial wealth, according to well known wealth-income ratios. We then divide total wealth into bank deposits and financial assets (stocks and bonds), again according to empirical evidence. On the other side, households are connected to some banks (again, the number of connection is derived by empirical observation) and households deposits give us banks liabilities, allowing us to correctly initialize the other items of bank's balance sheet. The same happens with the equity of the firms, derived by households shares, which allow us to initialize firms balance sheets, including their capital stock and considering also the loans on banks asset side. This process goes on for many steps and allows us to have a very consistent initialization of the model, where initial conditions have been chosen in order to keep realistic proportions between the different items of agents' balance sheets, and to correctly size stocks and flows dimensions. For instance, the debt-to-equity ratio of firms is initialized at 2, which is a realistic value for industrial companies. Risk (weighted) assets to equity ratio for banks is set to 5 . The wealth-to-income ratio for households is set around 70, with $30 \%$ of households wealth allocated into banks deposits, and the remaining $70 \%$ into financial assets. The initial value of the public debt is set to a value that, assuming a $10 \%$ unemployment rate and the initial productive capacity of firms, would set the debt-to-GDP ratio around to $100 \%$, which is in line with the Eurozone. This approach is actually part of an ex-ante validation method, called "input validation (Cirillo and Gallegati, 2012), where model's fitness is ensured by setting parameter values and variables ratios according to empirical analysis of actual data. The other pillar of input validation consists in incorporating into the model the 
fundamental structural behavioral and institutional features of real economic systems; models details in the Appendix show how we followed this approach.

In the following sections, results are presented from a qualitative and quantitative point of view, with the intention to examine and disclose the economic mechanisms that explain the obtained results. For every policy scenario, several tables report the ensemble averages of many relevant economic variables. Ensemble averages have been computed over the different seeds of the pseudo-random number generator; the relatively low standard errors, as reported within brackets in the tables, indicate that the ensemble averages provide reliable indications and that increasing further the number of seeds would not provide new meaningful information.

\subsection{Genesis of a crisis}

The Eurace model is characterized by endogenous business cycles and endogenous crises, as described for instance in Raberto et al. (2012). Gross domestic product shows three stylized behaviors: a long-run upward trend due to capital accumulation, alternate periods of growth and recession (business cycles), and sudden output falls that are usually followed by subsequent recoveries.

The origin of a typical crisis in the model can be summarized as follows. When the economy is in a boom period, characterized by high growth rate and nearly full employment, the increment of unit costs, due to the strong pressure on wages, as well as high aggregated demand cause an increase in the level of prices. Consequently, the central bank inflation targeting policy rule raises the base interest rate, then causing the increase of interest payments by firms. Figure 1 illustrates this mechanism for a representative simulation ${ }^{10}$ of the model, where the four different colours and line types refer to the four different selected policies. Figure 2 shows that the economic boom is driven by a credit expansion starting at year 9 , slowing down in the second half of the $11^{\text {th }}$ year, and growing again during year 12. Let us focus now on the fiscal compact scenario (FC) (we will compare the different policies later on), represented here by the continuous black line. Figure 3 shows a double dip recession starting in the second half of the $11^{\text {th }}$ year and becoming a severe crisis at the beginning of year 13 , after a temporary phase of economic recovery.

During the inflation of the credit bubble, the financial stability of the economic system is significantly weakened; firms financial indicators deteriorate (see figure 4). The interest bill paid by firms becomes very high with respect

\footnotetext{
${ }^{10}$ The representative simulation is given by a particular choice of the seed of the pseudo-random number generator. The four policy scenarios represented in the figures obviously refer to the same seed.
} 
to revenues; this outcome causes an increasing insolvency risk for firms due to growing interest rates. The bubble burst is actually triggered by insolvency bankruptcies of firms that are large enough to hurt banks equity, see figures ${ }^{11}$ 6 and 2 (top panel). In turn, banks equity contraction, due to the minimum capital requirements regulatory provisions, causes a credit crunch that affects firms possibilities to refinance their debt, thus leading to a vicious cycle that severely hits economic activity through illiquidity bankruptcy chains, see figure 5. Actually, previous works by some of the authors revealed that banking regulation is a key factor for preventing or mitigating financial crises. In particular, Teglio et al. (2012) discuss the role of capital adequacy ratio in destabilizing the economic system and exposing it to potential crises, while Cincotti et al. (2012b) shows that macro-prudential countercyclical banking regulations, based on unemployment control or credit supply control, can be more effective than Basel-II like micro-prudential regulation. This paper is focused on fiscal policy and therefore considers the same banking regulation for all simulations. Of course it would be interesting to study also the interactions between fiscal policy and banking regulations but this could be the subject for future work. The point here is to understand, ceteris paribus, the policy implications of different fiscal (and monetary) choices on both economic performance and stability.

\subsection{Dealing with the crisis: a comparison of fiscal policies}

Once the main determinants of the crisis in the Eurace model have been summarized, we want to discuss if fiscal policy can be a valid instrument to face it. Actually, it would be more accurate to say that we are comparing different combination of fiscal and monetary policies rather than fiscal policies tout court. In section 3 we presented the set of eight policies we are considering in the model; let us recall and briefly discuss them here.

Two fiscal policies, called "fiscal compact" (FC) and "stability and growth pact" (SGP), are used as standard scenarios. SGP means targeting a 3\% deficit over GDP ratio, whereas FC adds the constraint on government debt, which should not exceed $60 \%$ of GDP. Our definitions do not match exactly the official EU agreements ${ }^{12}$ but have merely the purpose to represent a stricter

\footnotetext{
${ }^{11}$ Note that we are still focusing only on the fiscal compact case, i.e. the continuous black line.

12 The Stability and Growth Pact is a set of rules designed to ensure that countries in the European Union pursue sound public finances and coordinate their fiscal policies (http://ec.europa.eu/economy_finance/economic_ governance/sgp/index_en.htm). The Treaty on Stability, Coordination and Governance in the Economic and Monetary Union, commonly known as Fiscal Compact, can be retrieved by request here: http://www.consilium.europa.eu/en/
} 
and a looser budget constraint for the government. Moreover, the standard scenarios are incrementally enriched with three complementary policies which relax fiscal rigidity. The first policy that has been considered on the top of the two basic scenarios is the activation of an "unemployment escape clause" $(\mathrm{U})$, stating that while the unemployment rate is above a given threshold, budget constraints on public deficit and debt are suspended. In the second complementary policy, the central bank is allowed to buy government bonds when U policy is active, performing a "quantitative easing" (QE) operation. Finally, the "fiscal accommodation" policy (FA) states that the combined U + QE policy is also complemented by an expansionary fiscal policy trying to stimulate the economy by reducing tax rates.

As a result we have eight different policy combinations, which are reported in the left side of our tables (see for instance table 6). On the other hand, time series plots present only four of the eight total policies. This choice has been motivated by a readability issue and by the fact that plots are mainly intended to visualize and explain the economic mechanisms that lead to the aggregated results presented in the tables. In this perspective, showing more policies together would be cumbersome and scarcely useful. The four policies shown in the time series plots are the basic versions of FC "fiscal compact" and SGP "stability and growth pact", along with their most expansionary versions, i.e. characterized by the addition of the unemployment escape clause (U), quantitative easing (QE), and fiscal accommodation (FA). The rational here is to show the "extreme" cases, remanding to the tables for the intermediate ones. Let us focus on the crisis that goes from the second half of year 11 to the end of year 13. Figure 3 clearly shows that counterbalancing a strict fiscal policy during recessions is crucial in order to avoid severe crises. In the case of the expansionary versions of the two basic policies, the deep crisis of year 13 is prevented. Figure 7 shows how the government avoids raising taxes in order to fulfill its budget commitments. Tax rates are kept low and the tax bill over GDP also remains low. However, looking at figure 8 showing the yearly government budget and deficit over GDP, it emerges that deficit and debt do not significantly increase during the crisis. This is true in particular for the case of the expansionary version of the fiscal compact (when a strict fiscal compact scenario is relaxed during high unemployment periods). The main point suggested here is that, during a crisis, the potential loss in GDP caused by a rigid "austerity" policy is much higher than the raise in deficit or debt caused by the temporary relaxing of such rigid measures. In other words it suggests that the fiscal multiplier is sufficiently high during recessions to recommend expansionary policies stimulating aggregated demand. Figure 1 shows that, during the crisis, the interest rate is very similar among all policy scenarios. Actually, the monetary policy is set by the Taylor rule in all cases and, when unemployment starts growing, the central bank decreases the

european-council/ 
interest rate to foster new investments. Nevertheless, if we observe banks and firms data in figures 2 and 4, we see remarkable differences. The deleveraging process characterized by both a sudden reduction of firms' debt and a crash of banks' equity is clearly reduced in the case of fiscal stimulus. Sustaining aggregate demand during the crisis has a chain of positive effects in the shortmedium run; first, it prevents sales crush, supporting firms' cash flows and then internal financing, thus decreasing bankruptcies risk; then, it defends banks from the swift equity losses caused by bankruptcies, allowing them to continue lending after also after year 13. On the contrary, it is interesting to notice the long lasting negative effect on lending by strict fiscal policies in figure 2, where (for FC and SGP policy scenarios) loans are strongly reduced and go back to pre-crisis levels only after almost five years (year 18). This is due to a vicious cycle where banks are not able to lend and to make enough profits to increase their equity capital (by retaining earnings); in turn, Basel II regulation do not allow banks with low equity capital to lend and therefore to improve their financial statement, leading to a long lasting stalemate in the economy.

\subsection{Fiscal scenarios from a wider perspective}

Results presented in the previous section convey a clear message: relaxing fiscal policy during a crisis is highly beneficial for the economy. The government should have as a primary objective during a crisis the reduction of unemployment by sustaining aggregated demand. Both in the case of "fiscal compact" and "stability and growth pact" regimes, a fiscal expansion has a positive impact during a crisis. This is what we observe in our results and what has been illustrated in some representative figures. Of course, we need also to consider the other side of the coin, by looking at public accounts.

Moreover, we need to generalize our results showing some robustness across the stochastic shocks to the model, or more precisely the different seeds used to simulate it. In this regard, we present a set of tables showing the ensemble averages of several economic indicators, computed over fifty different seeds.

The tables consider the complete set of the eight scenarios and allow us for some more detailed comments on the incremental design of policy strategies. In this respect, having many scenarios to compare, let us briefly outline a general discussion frame. The first comparison should be between "stability and growth pact" (SGP) and "fiscal compact" (FC), i.e., between a pure deficit targeting constraint and a stricter one involving also debt restrictions. Then, we consider the cumulative effect of the additional policies introduced in the previous sections, i.e., "unemployment escape clause" (U), "quantitative easing" (QE) and "fiscal accommodation" (FA). Furthermore, we will present and 
analyze both the outcomes of the model obtained from the entire simulation time span and the specific results concerning periods of crisis.

Tables 7 and 8 show the ensemble average values of some indicators characterizing periods of crisis. In particular they show the average number of occurrences of at least two consecutive months with unemployment higher than ${ }^{13} 10 \%$ (Table 7 ) or $20 \%$ (Table 8 ). The two tables also show the average duration of a crisis, measured in consecutive months, and the probability for a firm to go bankrupt during this period. Finally, the maximum unemployment rate during the crisis period is shown. Furthermore, figure 9 shows the inverse cumulative distribution function of bankruptcies during a bimester for different policy scenarios (considering all seeds). It has to be read as the probability of having more that a given number of bankruptcies during two consecutive months. Results clearly suggest that, when no fiscal relief mechanism is applied during crises, bankruptcies are more likely to happen and the economy is more unstable. With a pure "fiscal compact" strategy the probability of having a very severe crisis, i.e., charcaterized by unemployment higher than $20 \%$ during a simulation, is $80 \%$ (see table 8 ) and the average duration of the crisis is nine month and a half. The bankruptcy probability for a firm is $33 \%$ and the maximum unemployment rate is almost $40 \%$ during the crisis. The situation with a pure "stability and growth pact" strategy is less catastrophic but still severe, with a $50 \%$ crisis probability per simulation and a $20 \%$ bankruptcy probability for a firm during a crisis. On the other hand, the beneficial effect of relaxing the fiscal constraint during crises appears quite distinctly from the data. In particular, in the FC case, when we simply allow for the unemployment escape clause, all the crisis indicators perform much better. Similar results hold for the SGP case both in table 7 and 8. Going more into the detail, the activation of the unemployment escape clause, which rescinds the fiscal constraint above a given threshold of unemployment rate, has always a positive effect on the economy during crises, as tables 7 and 8 clearly show. Concerning the overall economic performance, the general macroeconomic indicators are also notably improved by activating the escape clause, as shown in table 10. This is of course related to the higher stability of the economic system during crises, which allows for a better performance of the economy. As expected, looking at public finances in table 6 , we observe both in the $\mathrm{FC}+\mathrm{U}$ and SGP $+\mathrm{U}$ cases an increase both in public debt and deficit over GDP and in the bond yield. However, over 25 years, public finances do not seem to be under strain, especially in the $\mathrm{FC}+\mathrm{U}$ case, where deficit is around $3 \%$ of the GDP and debt is at $110 \%$.

The next incremental policy step concerns the introduction of the quantitative easing mechanism. In the QE case, when the unemployment escape clause is activated, the central bank is allowed to buy government bonds in the sec-

$\overline{{ }^{13} \text { We }}$ use this condition as a proxy of a crisis. 
ondary market. What emerges from the computational experiments is that running QE during crises is not really favorable with respect to the simple activation of the unemployment escape clause. Indeed, QE has a positive effect in keeping low the government bond yield, due to central bank's demand for bonds, and in slightly improving public finances. The level of prices is also unaffected, probably because QE is activated only during crises when the unemployment rate is high, wages do not raise, and firms have room to increase production by hiring new workers with little effect on wages and then prices. However, the QE monetary expansion does not help the economy in a substantial way. Both during crises and during the overall 25 years of simulation, all economic indicators get marginally worse. Both in case of both FC and SGP underlying fiscal stance, bankruptcy probability and maximum unemployment rate raise during crisis periods, and the average 25 years GDP growth also declines with respect to the unemployment escape clause only case. The slightly poorer economic performance of quantitative easing, relatively to the scenarios based on the unemployment escape clause only, improves substantially when coupled with a reduction of taxes during high unemployment periods. This scenario is represented in the tables by activating the fiscal accommodation option FA. The combination of $\mathrm{QE}$ and FA seems to give good results, especially in the case of an underlying fiscal compact framework. The average number of crises during the simulation time span drops consistently (below 1 in table 7 and around 0.3 in table 8, with both the underlying FC and SGP cases), as it does the average duration of the crisis, showing the minimum values both under fiscal compact and SGP. The long-run economic indicators are also very good in both cases, showing a low unemployment rate combined with a high GDP growth rate (table 10). Government data show of course a drastic decrease in the overall tax rate, due to reduction of fiscal pressure during crisis periods, along with a deterioration of government finances. However, comparing the two fiscal regimes of FC and SGP, the state of public accounts seems more sustainable in case of fiscal compact, where deficit is $4.27 \%$ of the GDP and debt is slightly higher that $120 \%$. On the other hand, when the underlying SGP fiscal regime is adopted, public accounts reach a more critical level with debt over $160 \%$ and deficit close to $7 \%$ of the GDP.

\subsection{Policy insights and boundary of the model}

In this last section we would like to mention the potential implications of the study for policy makers, considering the range of applicability of the model and its limitations.

The main policy suggestion that can be extracted from our study is that a base of rigorous fiscal policy combined with local flexibility is the best solution. The general rule for governments to keep their deficit under strict control should 
be respected, except for periods of strong recession or crisis. Both the stability and growth pact and the fiscal compact scenarios seem to perform well if and only if some mechanisms of fiscal relaxation and monetary accommodation are considered during bad times. These suggestions highlight the importance of aggregate demand during recessions and seem very much consistent with traditional Keynesian economics. Our analysis, however, is not limited to the short run, because the model includes investments and capital accumulation; and simulations are actually run for a quite long time span (25 years). Moreover, the model is also able to take into account the public debt dynamics and its effects on the economy, as shown and discussed in the previous sections.

We just described the main policy advice our model can give, but of course the real world is always more complicated that any model and the main limitation of the Eurace model so far is that it represents a closed economy. For example, as pointed out in the introduction, the recent case of the European Monetary Union (EMU) is particularly relevant in the debate on fiscal policies during recessions. For this purpose, our model design misses some elements, e.g. the co-existence of different fiscal policies, followed by each EMU member State, and a single monetary policy, as well as the significant outflows and inflows of goods and financial assets between the EMU and the global economy. These elements imply many additional adjustment processes in the economy that we do not consider.

Furthermore, we disregard at least two important economic and financial features that played an important role during the last recession: the real estate market and the securitization mechanism. These mechanisms act as additional layers in the financial system, potentially raising leverage and generating bubbles that cause the expansion of credit cycles and mine the stability of the economy, as in the case of a credit-driven bubble and burst in the housing market, see e.g. Erlingsson et al. (2014) for a recent agent-based investigation. However, we think that the core of these macroecomic fluctuations has been already captured by the model presented in this study; moreover, both the extension to a multi-country model setting and the inclusion of additional sources generating credit-driven boom and bust cycles, like housing market and securitization, could be considered as further refinement on the same line of investigation and will be the subject of future model enrichment within the EU project Symphony ${ }^{14}$.

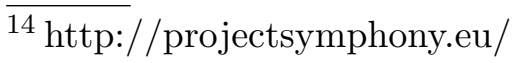




\section{Concluding remarks}

This paper investigates the effects of different fiscal and monetary policy combinations by simulating an evolutionary agent-based economy. Particular attention is devoted to the study of the economy on the edge of a crisis, in order to understand the policy mixture that can be more helpful both in the short run, to overcome the crisis, and in the long run, to have a sustainable growth path and debt.

Fort this purpose we considered two base policies whose aim is to keep public budget under control (i.e., fiscal compact and stability and growth pact), integrating them with fiscal and monetary stimulus during recessions. Our results show that targeting debt or deficit over GDP ratios, irrespective of the existing economic conditions, leads to very poor outcomes and high instability. Expansionary fiscal policies during recessions are very helpful to reduce both crises duration and the number of total crises in a time span of 25 years. Therefore we find that counter-cyclical fiscal policies, supported by adequate monetary policies, are recommended in order to enhance growth and stability. The rationale behind these results is the need to counterbalance credit driven business cycles which can lead too boom and bust dynamics if neglected. These results are in line with the Keynesian lesson, emphasizing the importance of government intervention during recessions to stimulate aggregate demand.

The policy recommendation, embedded in the current economic debate, is therefore to keep under control public and private debt during goods times, acting with counter-cyclical and macro-prudential policies (see also Teglio et al. (2012) about the key role of private debt regulation). This is the main way to prevent an excessive leverage with potential instability and bubbles. Besides, expansionary fiscal policy and monetary accommodation should be vigorously used during bad times in order to offset the loss in unemployment and aggregate demand. It's worth remarking that the duality of this policy is important because budgetary rigour during good times will help to avoid the explosion of public debt which could hurt the economy in the long run.

We have already explained in the previous section some limitations of the current model. We would like to sketch here the model enrichments we are currently developing. First, the inclusion of a housing market with bail-in bail-out mechanism for defaulting banks. Second, the addition of more sophisticated and realistic financial instruments mimicking the securitization mechanism. Third, a multi-country environment where both monetary union and monetary independence are considered. 


\section{Acknowledgment}

The authors acknowledge EU-FP7 collaborative project SYMPHONY ${ }^{15}$ under grant no. 611875 .

\section{Appendix}

\section{Eurace agents}

In the Appendix, we describe in details agents' decision making and interactions through different market settings. Agents' state variables are the balance sheet entries described in Table 8; in the following, we report the equations characterizing agents' behaviour and decision making. Agents' formation of expected values, wishes or plans about key economic variables are also reported and denoted with the superscript $e$, while wishes or plan are marked by an hat on the variable symbol. Tables 1, 2, 3, 4 and 5 include agents' parameters set for the simulations' initialization, used to produce the presented results.

\section{Scheduling}

The elementary simulation time step can be considered a calendar day; however, most agents' decisions and economic events occur at a weekly, monthly, or even yearly periodicity, and are asynchronous. For instance, trading of stocks and government bonds is active every day; consumption budget decisions are made monthly by households but purchases are made on weekly basis; firms' decision about production planning, new hirings, pricing, investments and financing are characterized by a monthly periodicity but are asynchronous, i.e., each firm makes its monthly production/investments decisions at a particular day, henceforth activation day, of the calendar month. ${ }^{16}$

Finally, decisions by policy makers can be taken on a monthly or yearly basis. In particular, the policy rate is set by the central bank at the beginning of each calendar month, at the same time the government sets the amount of bonds to issue during the month to address its liquidity needs; tax rates instead are usually adjusted on a yearly basis according to the predefined fiscal policy.

\footnotetext{
$\overline{15}$ www.projectsymphony.eu

${ }^{16}$ A calendar month is defined as a set of 20 days
} 
We provide below a sequential list of the key decision variables each consumption goods producer, henceforth firm $f$, plans or decides once a month, at its particular activation day:

- the expected demand of consumption goods $q_{C_{f}}^{e}$ it will face, based on a linear interpolation of past $T_{C}$ monthly sales;

- the desired level of inventories $\widehat{I}_{f}$ to meet expected demand $q_{C_{f}}^{e}$;

- the production needs $\bar{q}_{C_{f}}$ necessary to accumulate the desired level of inventories $\widehat{I}_{f}$, i.e., $\bar{q}_{C_{f}}=\max \left[0, \widehat{I}_{f}-I_{f}\right]$;

- the production plan $\widehat{q}_{C_{f}}$ as a linear combination ${ }^{17}$ of production needs $\bar{q}_{C_{f}}$ and previous month production $q_{C_{f}}$, i.e., $\widehat{q}_{C_{f}}=(1-\lambda) \bar{q}_{C_{f}}+\lambda q_{C_{f}}$;

- the labor force $\widehat{N}_{f}$ needed and the amount of physical capital $\widehat{K}_{f}$ needed to meet the desired production plan, given the present endowment of capital goods $K_{f}$, the present number of employees $N_{f}$, and the Cobb-Douglas production technology, as follows:

$$
\begin{aligned}
& \widehat{N}_{f}=\left(\frac{\widehat{q}_{C_{f}}}{\gamma\left(K_{f}\right)^{\beta}}\right)^{\frac{1}{\alpha}} \\
& \widehat{K}_{f}=\left(\frac{\widehat{q}_{C_{f}}}{\gamma\left(N_{f}\right)^{\alpha}}\right)^{\frac{1}{\beta}}
\end{aligned}
$$

where $\gamma$ is the total factor productivity, while $\alpha$ and $\beta$ are the output elasticities of labor and capital, respectively;

- the labor demand $N_{f}^{d}$ given by the difference, if not negative, between the needed labor force $\widehat{N}_{f}$ and the present number of employees $N_{f}$;

- the planned investment in new capital goods $\widehat{\Delta K}_{f}$, which is bounded by the difference $\widehat{K}_{f}-K_{f}$ and maximizes the present value of the foreseen additional revenues $p_{C_{m}}^{e} \Delta_{m} q_{C_{f}}$, originated by the investment at any next month $m$, after deducting the investment costs at the capital goods price $p_{K}$, as follows:

$$
\widehat{\Delta K}_{f}=\underset{\widehat{\Delta K}_{f} \leq\left(\widehat{K}_{f}-K_{f}\right)}{\arg \max }\left(-p_{K} \widehat{\Delta K}_{f}+\sum_{m} \frac{p_{C_{m}}^{e} \Delta_{m} q_{C_{f}}}{\left(1+\tau_{C}\right)\left(1+\frac{r_{K_{f}}}{12}\right)^{m}}\right) ;
$$

where $\tau_{C}$ is the value added tax on consumption, $p_{C_{m}}^{e}$ is the expected price level at any future month $m$ and $\Delta_{m} q_{C_{f}}$ is the additional output given by the planned investment. The latter two quantities are estimated as follows:

$$
p_{C_{m}}^{e}=p_{C}\left(1+\frac{\pi_{C}^{e}}{12}\right)^{m}
$$

\footnotetext{
$\overline{17}$ This provision is aimed to smooth the production plan over time and then reduce oscillations in input demand.
} 


$$
\Delta_{m} q_{C_{f}}=\gamma N_{f}^{\alpha}\left(K_{f}+\left(1-\xi_{K}\right)^{m} \widehat{\Delta K}_{f}\right)^{\beta}-\gamma N_{f}^{\alpha} K_{f}^{\beta}
$$

where $\pi_{C}^{e}$ is the expected yearly inflation rate $^{18}$ and $\xi_{K}$ is the capital goods constant monthly depreciation rate ${ }^{19}$. Finally, $r_{K_{f}}$ is the yearly average cost of capital of firm $f$; for the sake of simplicity, this cost is estimated by averaging the cost of different loans.

- the total liquidity needs $\widehat{M}_{f}$ given by the foreseen cost of planned capital goods investments $p_{K} \widehat{\Delta K}_{f}$, planned labor costs $w_{f} \widehat{N}_{f}$, debt interests $\mathcal{I}_{f}$ and the installment $\delta_{D} D_{f}$ of debt repayment, taxes ${ }^{20} \mathcal{T}_{f}$ and the foreseen dividend payout $n_{E_{f}} d_{f}$, i.e.,

$$
\widehat{M}_{f}=p_{K} \widehat{\Delta K}_{f}+w \widehat{N}_{f}+\mathcal{I}_{f}+\delta_{\ell} D_{f}+\mathcal{T}_{f}+n_{E_{f}} d_{f}
$$

where $\delta_{\ell}$ is the monthly fraction of debt repayment ${ }^{21}$ and, considering the yearly interest rate $r_{f, b_{i}}$ paid by firm $f$ on its $i$-th debt of amount $D_{f, b_{i}}$ to bank $b$, monthly debt interests payments are given by:

$\mathcal{I}_{f}=\sum_{b, i} \frac{r_{f, b_{i}}}{12} D_{f, b_{i}}$;

- the amount of new loan $\widehat{\ell}_{f}$ requested to the banking system, given by the difference, if not negative, between $\widehat{M}_{f}$ and present liquidity $M_{f}$;

- if rationed in the credit market, i.e., the new loan $\ell_{f}$ received is lower than $\hat{\ell}_{f}$, the amount of new shares $\Delta n_{E_{f}}$ to issue in the stock market, given by:

$$
\Delta n_{E_{f}}=\frac{\widehat{M_{f}}-\ell_{f}-M_{f}}{p_{E_{f}}} ;
$$

where $p_{E_{f}}$ is the present stock price;

- if rationed also in the stock market, the reduction of the costs under its control, in order to make the total financial needs consistent with the available liquidity. First, the total dividend payout is reduced up to zero, then, if still not sufficient, the investment plan is sized down and, eventually, the production plan as well. ${ }^{22}$

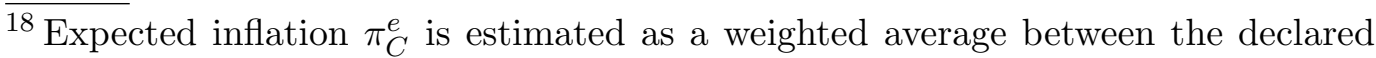
central bank inflation target $\widehat{\pi}_{C B}$ and the present yearly realized inflation rate $\pi_{C}$, i.e., $\pi^{e}=\omega_{\pi} \widehat{\pi}_{C B}+\left(1-\omega_{\pi}\right) \pi_{C}$, where the weight parameter $\omega_{\pi}$ can be considered as a sort of trust of private agents on the central bank policy action.

${ }^{19}$ Due to capital depreciation, the cash flows given by the additional revenues of investments decrease exponentially over time and therefore the sum of Eq. 3 is truncated when the addend is lower than a positive very small threshold.

${ }^{20} \mathcal{T}_{f}$ include taxes on corporate earnings and the value added tax (VAT) paid by consumers. VAT is collected by firms and transferred by them to the government.

${ }^{21}$ See table 2

${ }^{22}$ If the available liquidity is not even sufficient to meet compulsory payments, i.e. debt service and taxes, then the firm enters a process called illiquidity bankruptcy, where it fires all its employees and stay inactive till it is able to raise the necessary 
As soon as the decisions above are taken, the firm pays its financial commitments, namely, debt interests and debt installments, taxes on corporate earnings, the value added tax and dividends to shareholders. Then, in the same activation day, the firm enters factors (labor and capital goods) markets to fulfill its production and investment plans, also considering possible revisions downward due to rationing in the credit and stock markets. In particular, if the number of employees is higher than needed, the firm fires workers in excess, otherwise it starts the first labor market session to hire new additional employees. If the firm is unable to hire all the needed new employees, it increases its wage offer by a fixed percentage $\xi_{w}$ and starts a second market session. If rationed again, it increases again its wage offer but exits the labor market ending up with a number of employees $N_{f}$ lower than the planned one. Monthly wages are paid in advance at the end of the labor market sessions. ${ }^{23}$ Then, the firm purchases the amount of new capital goods according to fulfill its investment plan. New capital goods are immediately delivered and summed up to the existing capital endowment. We assume that firms are never rationed in the capital goods market. Finally, firms execute the production process that, following the Cobb-Douglas technology, delivers immediately an amount of new consumption goods $q_{C_{f}}$ given by the new levels of labor $N_{f}$ and capital $K_{f}$, as follows:

$$
q_{C_{f}}=\gamma N_{f}^{\alpha} K_{f}^{\beta}
$$

The new produced goods are summed to present inventories and made available for sale to households during the 20 business days following firms' activation days. Finally, the new sale price $p_{C_{f}}$ is set based on a fixed mark-up $\mu_{C}$ on the overall unit $\operatorname{costs} c_{u_{f}}$, i.e.,

$$
p_{C_{f}}=\left(1+\mu_{C}\right) c_{u_{f}}
$$

where overall unit costs are a weighted average of inventories' unit $\operatorname{costs} c_{u_{f}}^{(I)}$ and new produced goods unit $\operatorname{costs} c_{u_{f}}^{(q)}$, given by labor costs and the the interest bill, as follows:

$$
c_{u_{f}}=\frac{I_{f} c_{u_{f}}^{(I)}+q_{C_{f}} c_{u_{f}}^{(q)}}{I_{f}+q_{C_{f}}} \quad c_{u_{f}}^{(q)}=\frac{w_{f} N_{f}+\mathcal{I}_{f}}{q_{C_{f}}}
$$

funds in the stock market. It is worth remembering that the model foresees also a more severe case called insolvency bankruptcy, which is triggered whenever the equity of the firm becomes negative and therefore involves also a debt restructuring process with a consequent loan and equity write-off for lending banks.

${ }^{23}$ Further details about the Eurace labor market are provided in Dawid et al. (2014). 
After twenty days, the day before a new activation day occurs, each firm calculates its monthly income statement along with monthly interests, taxes and net earnings; then computes the share of dividend payout as a fraction $\xi_{d}$ of net earnings, if positive, and updates its balance sheet. ${ }^{24}$

\begin{tabular}{|c|l|l|}
\hline \multicolumn{2}{|l|}{ Firm Parameters } & \multicolumn{1}{|c|}{ Name } \\
\hline Symbol & \multicolumn{1}{|c|}{ Value } \\
\hline$\lambda$ & previous month production weight & 0.5 \\
\hline$\gamma$ & total factor productivity & 1.5 \\
\hline$\alpha$ & output elasticities of labor & 0.662 \\
\hline$\beta$ & output elasticities of capital & 0.338 \\
\hline$\xi_{K}$ & $\begin{array}{l}\text { capital goods constant monthly depreciation } \\
\text { rate }\end{array}$ & 0.005 \\
\hline$\xi_{w}$ & monthly wage percentage increase & 0.01 \\
\hline$\mu_{C}$ & fixed mark up & 0.1 \\
\hline$\xi_{d}$ & fraction of net earnings paid as dividends & 0.75 \\
\hline$\omega_{\pi}$ & central bank inflation target weight & 0.5 \\
\hline
\end{tabular}

\section{Capital goods producer}

There is just one type of technology for capital goods. Capital goods are produced on request and therefore do not generate inventories. Energy and raw materials are the only factor of production and are assumed to be imported from abroad. The price of capital goods is set according to a mark-up on input prices, which are exogenously given. Profits of investment good producers are distributed in equal shares among all households. Thus, the amount paid by consumption goods producers for investment goods is partially (the part related to mark-up) channelled back into the economy. In the experiments performed in this study, however, in order to separate the effects of the different

${ }^{24}$ In particular, each firm updates the value of its net worth or equity. If the equity becomes negative the firm is declared insolvent and enters a special process termed insolvency bankruptcy, where the its fires all its employees, undergoes a restructuring of its debt with a related loan write-off and a corresponding equity loss on creditor banks' balance sheets, and stays inactive for a period of time after which it enters again the market with a healthy balance sheet. Physical capital of insolvent firms is therefore not lost but remains inactive for a while. 
fiscal policies from the exogenous dynamics of raw materials and energy, the price of these commodities has been conventionally set to zero, and the price of capital goods is set to a constant value. The model can therefore be considered as a closed economy where the revenues of the capital goods producer coincide with its profits and are fully channelled back into Eurace economy through dividends and tax payments.

\section{Banks}

Banks are always active on a daily basis being ready to receive loans requests from firms. As outlined in the previous paragraph, each firm sends a loan request at its activation day and firms' activation days are uniformly distributed over the calendar month. Whenever a bank receive a loan request $\hat{\ell}_{f}$ by a firm $f$, the request is evaluated and a loan eventually offered according to the following steps:

- the bank assesses the risk of the new loan; first, it estimates the default probability $\pi_{D_{f}}$ of the prospective borrower, based on its leverage, along the lines of the Moodys KMV model (Saunders and Allen, 2010); then, it assesses the risk weight $\omega_{\widehat{\ell}_{f}}$ of the new loan through an ad-hoc cubic function approximating ${ }^{25}$ the so-called Basel II internal ratings approach, i.e.,

$$
\pi_{D_{f}}=\frac{D_{f}+\widehat{\ell}_{f}}{D_{f}+\widehat{\ell}_{f}+E_{f}} \quad \omega_{\widehat{\ell}_{f}}=2.5\left(\pi_{D_{f}}\right)^{3} .
$$

The rationale is that the lower the capital base of the borrower with respect to its debt, the higher the likelihood of default is, and then the loan's risk, because of possible equity losses due to negative earnings;

- the bank $b$ checks if its risk-weighted loan portfolio including the new prospective loan, weighted by its risk, still fulfils regulatory capital requirements, i.e. if the following condition holds:

$$
E_{b} \geq \Psi\left(\sum_{i} \omega_{\ell_{i}} \ell_{i}+\omega_{\widehat{\ell}_{f}} \widehat{\ell}_{f}\right)
$$

where $\Psi$ is the so called capital adequacy ratio, i.e. a policy parameter, ranging from 0 to 1 , set by the regulatory provisions for the banking system;

- the bank $b$ rejects the loan requests or otherwise it offers to firm $f$ a loan amount $\ell_{b, f} \leq \hat{\ell}_{f}$ to the extent the capital requirement condition of Eq. 12 is satisfied; the new loan is offered for a duration of $T_{\ell}$ months at a yearly interest rate $r_{b, f}$ given by central bank rate plus a stochastic markup depending of the loan risk $\omega_{\ell_{f}}$.

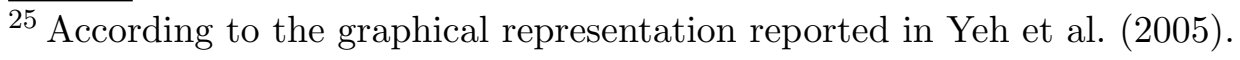


The borrowing firm ranks the loan offers received according to their interest rates and accepts the loan offers with the lowest rates up to the amount of money requested.

At the end of any calendar month, each bank computes its income statement along with income taxes and net earnings, then decides the dividends payout, to be paid each first day of the calendar month, then updates its balance sheet. All net earnings, if positive, are paid out as dividends, unless the bank had to decline loan requests because of the capital adequacy ratio constraint. In this case, the bank retains all net earnings to increase its equity base.

\begin{tabular}{|c|l|l|}
\hline \multicolumn{2}{|l|}{ Bank Parameters } \\
\hline Symbol & \multicolumn{1}{|c|}{ Name } & Value \\
\hline$\psi$ & capital adequacy ratio & 0.10 \\
\hline$T_{\ell}$ & loan duration (months) & 24 \\
\hline$\delta_{\ell}$ & monthly fraction of debt repayment & $1 / T_{\ell}$ \\
\hline
\end{tabular}

\section{Households}

Households are always ready on a daily basis to make a financial trade and to look for a new job, if unemployed. In particular, at any daily simulation step, each household has a given exogenously probability $\pi_{H}$ to change the allocation of its financial portfolio. In this case, the household forms beliefs about the expected returns of all financial assets (firms' shares and government bonds) according to a weighted average of fundamentalist, random and chartist prototype expected returns, then she/he computes the new "optimal" asset allocation according to a preference structure based on the myopic loss aversion hypothesis of prospect theory (Kahneman and Tversky, 1979; Benartzi and Thaler, 1995); finally, the household issues buy and sell orders to get the desired optimal allocation. Full details about households' financial beliefs and preference and the working of the financial market are provided in Raberto et al. (2008b); Teglio et al. (2009).

After financial market transactions are over, unemployed households enter the labor market to evaluate pending job offers. Here, households are randomly queued to apply to the set of available jobs characterized by the highest wages, provided that they are higher than their reservation wage. ${ }^{26}$. If a household is not successful in getting a new job, her/his reservation wage is decreased by a constant rate $\delta_{w}$ and the household re-evaluates again pending job offers. If the job search is again unsuccessful, household's reservation wage is again

\footnotetext{
$\overline{26}$ The reservation wage is set equal to the last received wage and is therefore heterogeneous among households
} 
decreased by the same rate $\delta_{w}$ and she/he leaves the labor market till next daily simulation step. Further details about the Eurace labor market are provided in Dawid et al. (2014).

Employed households receive their salary from their employers (the firms) on a monthly basis but at different days which coincide with firms' activation days, i.e. the dates when they have been hired. Salaries $w_{f}$ are identical among the employees of the same firm $f$ but differ across firms, according to the labor market outcome, because firms raise their wage offer whenever they are unable to find the needed employees. Households employed in the public sector receive from the government a public wage $w_{g}$, which is set equal to the average wage in the private sector in the last 12 months. Unemployed households receive on a monthly basis an unemployment benefit ${ }^{27}$ from the government; the benefit is paid the same day of the month the household is fired. The day of the month a households receive the salary or the unemployment benefit, it gets also a transfer payment ${ }^{28} y_{T_{h}}$ from the government and computes and pays taxes on both the labor income $y_{L_{h}}$ (the salary or the unemployment benefit) and the capital income, given by the stocks' dividends $y_{E_{h}}$ and bonds' coupons $y_{B_{h}}$ received during the previous 20 days. The same day the household receives its labor/unemployment benefit income, it also determines its monthly consumption budget $\mathcal{C}_{h}$, which is modelled according to the theory of bufferstock saving behavior (Carroll, 2001; Deaton, 1992), stating that households consume more or less than their net income with the aim to get a target ratio $\lambda_{C}$ of liquid wealth ${ }^{29} W_{h}$ to total net income $y_{h, \text { net }}$. In particular, being the total net income $y_{h, \text { net }}$ given by:

$$
y_{h, \text { net }}=\left(1-\tau_{N}\right) y_{L_{h}}+\left(1-\tau_{K}\right)\left(y_{E_{h}}+y_{B_{h}}\right) \text {, }
$$

where $\tau_{N}$ and $\tau_{K}$ are the tax rates on labor and capital income, respectively, the monthly consumption budget $\mathcal{C}_{h}$ is determined by:

$$
\mathcal{C}_{h}=y_{h, \text { net }}+\xi_{C}\left(W_{f}-\lambda_{C} y_{h, \text { net }}\right)
$$

where $\xi_{C}$ gives the speed of adjustment of consumption to meet the desired wealth to income target ratio. Therefore, households consume more (less) than their net income if their liquid wealth if higher (lower) than a multiple $\lambda_{C}$ of their net income.

\footnotetext{
$\overline{27}$ The unemployment benefit is set at a fraction $\delta_{U}$ of the last salary received by the households

${ }^{28}$ The transfer payment is set to a fraction $\delta_{T}$ of the average wage paid by firms

${ }^{29}$ The liquid wealth is given by liquidity plus the market value of the stocks and government bonds portfolio.
} 


\begin{tabular}{|c|l|l|}
\hline \multicolumn{2}{|l|}{ Household Parameters } \\
\hline Symbol & \multicolumn{1}{|c|}{ Name } & Value \\
\hline$\xi_{C}$ & adjustment speed of consumption & 0.01 \\
\hline$\lambda_{C}$ & target ratio of liquid wealth to net income & 70 \\
\hline$\pi_{H}$ & $\begin{array}{l}\text { probability of financial asset portfolio alloca- } \\
\text { tion }\end{array}$ & 0.1 \\
\hline$\delta_{w}$ & constant rate of reservation wage decrease & 0.01 \\
\hline
\end{tabular}

Central Bank

The central bank is in charge of monetary policy, which consists of two main tasks: to provide liquidity in infinite supply to banks, whenever they need it, and to set the monthly policy rate $r_{C B}$, which is the cost banks pay when borrowing liquidity. In particular, at the beginning of each month, the central bank collects the information about the latest values of inflation and unemployment in the Eurace economy and sets the policy rate $r_{C B}$ for the incoming month as follows:

$$
r_{C B}=\pi_{C}+r^{*}+\omega_{\pi}\left(\pi_{C}-\widehat{\pi}_{C}\right)+\omega_{v}\left(\widehat{v}_{N}-v_{N}\right),
$$

where $\pi_{C}$ is the last realized value of the inflation rate, measured in a yearly moving window, $r^{*}$ is the assumed real interest rate, $\widehat{\pi}_{C}$ is the inflation target, $\widehat{v}_{N}$ is the unemployment target, and $v_{N}$ is the previous month unemployment rate.

It is worth noting that Eq. 15 resembles the well known Taylor rule (Taylor, 1993), but departs from the standard one for including a sort of unemployment gap, i.e., $\left(\widehat{v}_{N}-v_{N}\right)$, instead of the usual output gap. The reason of this choice is practical as it is not obvious, in particular in an agent-based model, how the output gap could be measured. However, the two measures are clearly strongly interconnected and the unemployment gap used in Eq. 15 is certainly a satisfactory indicator of economic recession.

\begin{tabular}{|c|c|l|}
\hline \multicolumn{2}{|c|}{ Central Bank Parameters } & \\
\hline Symbol & Name & Value \\
\hline$r^{*}$ & assumed real interest rate & 0.02 \\
\hline
\end{tabular}

Continued on next page 
Table 4 - Continued from previous page

\begin{tabular}{|c|l|l|}
\hline Symbol & \multicolumn{1}{|c|}{ Name } & Value \\
\hline$\widehat{\pi}_{C}$ & inflation target & 0.02 \\
\hline$\widehat{v}_{N}$ & unemployment target & 0.0 \\
\hline$\omega_{\pi}$ & inflation weight & 0.2 \\
\hline$\omega_{v}$ & unemployment weight & 0.2 \\
\hline
\end{tabular}

\section{Government}

The government is in charge of both fiscal and welfare policies. The revenues of the government come from taxes that are applied to four sources: corporate earnings, consumption, capital income (dividends and bond coupons) and labour income (wages and unemployment benefits). Taxes are collected on a monthly basis, while the four related tax rates are usually revised yearly, depending on the particular fiscal policy adopted, as outline in section 3.

Governments expenditures include the labor cost of public sector employees ${ }^{30}$, unemployment benefits, transfers and government bond coupons.

On a monthly basis, if in short of liquidity, the government decides to issues new bonds, which are directly sold in the bond market at a discounted price with respect to the market price $p_{G}$, and then purchased by households.

Government bonds are perpetuities that pay a monthly fixed coupon that depends on the bond nominal value $\widehat{p}_{G}$ and the fixed nominal yearly interest rate $r_{G}$. Government bond market price depends on households' trading behavior, which, like in the stock market case, is characterized by a mix of chartists, random and fundamentalist typical patterns. In particular, in the case of bonds, the fundamental price is determined by discounting the supposedly risk-free future bond coupons with the central bank policy rate.

\begin{tabular}{|c|l|l|}
\hline \multicolumn{2}{|c|}{ Government Parameters } \\
\hline Symbol & \multicolumn{1}{|c|}{ Name } & Value \\
\hline$r_{G}$ & fixed nominal yearly rate on bonds & 0.02 \\
\hline$\delta_{U}$ & $\begin{array}{l}\text { fraction of last wage setting the unemployment } \\
\text { benefit }\end{array}$ & 0.7 \\
\hline
\end{tabular}

Continued on next page

\footnotetext{
$\overline{30}$ The number of public employees is set at a fixed percentage $\delta_{G}$ of the total household population.
} 
Table 5 - Continued from previous page

\begin{tabular}{|c|l|l|}
\hline Symbol & \multicolumn{1}{|c|}{ Name } & Value \\
\hline$\delta_{T}$ & $\begin{array}{l}\text { fraction of the average wage level setting the } \\
\text { transfer payment }\end{array}$ & 0.5 \\
\hline$\delta_{G}$ & $\begin{array}{l}\text { fraction of public employees among household } \\
\text { population }\end{array}$ & 0.2 \\
\hline
\end{tabular}




\section{References}

Akerlof, A. G. (2002). Behavioral macroeconomics and macroeconomic behavior. American Economic Review, 92(3):411-433.

Alesina, A. and Ardagna, S. (2010). Large changes in fiscal policy: Taxes versus spending. In Tax Policy and the Economy, Volume 24, pages 35-68. The University of Chicago Press.

Ashraf, Q., Gershman, B., and Howitt, P. (2014). How inflation affects macroeconomic performance: an agent-based computational investigation. Macroeconomic Dynamics, FirstView:1-24.

Assenza, T., Delli Gatti, D., and Grazzini, J. (2015). Emergent dynamics of a macroeconomic agent based model with capital and credit. Journal of Economic Dynamics and Control, 50:5 - 28.

Auerbach, A. and Gorodnichenko, Y. (2012). Measuring the output responses to fiscal policy. American Economic Journal: Economic Policy, 4(2):1-27.

Benartzi, S. and Thaler, R. H. (1995). Myopic loss aversion and the equity premium puzzle. The Quarterly Journal of Economics, 110(1):73-92.

Carroll, C. D. (2001). A theory of the consumption function, with and without liquidity constraints. Journal of Economic Perspectives, 15(3):23-45.

Caverzasi, E. and Godin, A. (2015). Post-keynesian stock-flow-consistent modelling: a survey. Cambridge Journal of Economics, 39(1):157-187.

Cincotti, S., Raberto, M., and Teglio, A. (2010). Credit money and macroeconomic instability in the agent-based model and simulator eurace. Economics: The Open-Access, Open-Assessment E-Journal, 4(2010-26).

Cincotti, S., Raberto, M., and Teglio, A. (2012a). The Eurace macroeconomic model and simulator. In Agent-based Dynamics, Norms, and Corporate Governance. The proceedings of the 16-th World Congress of the International Economic Association, volume II. Palgrave.

Cincotti, S., Raberto, M., and Teglio, A. (2012b). Macroprudential policies in an agent-based artificial economy. Agent-based Models and Economy Policy, pages 205-234.

Cirillo, P. and Gallegati, M. (2012). The empirical validation of an agent-based model. Eastern Economic Journal, 38(4):525-547.

Colander, D., P. Howitt, A. P. Kirman, A. L., and Mehrling, P. (2008). Beyond DSGE models: toward an empirically based macroeconomics. American Economic Review, 98(2).

Dawid, H., Harting, P., and Neugart, M. (2014). Economic convergence: Policy implications from a heterogeneous agent model. Journal of Economic Dynamics and Control, 44:54 - 80.

De Grauwe, P. and Ji, Y. (2012). Self-fulfilling crises in the eurozone: an empirical test. Journal of International Money and Finance, 34:15-36.

Deaton, A. (1992). Household saving in LDCs: credit markets, insurance and welfare. The Scandinavian Journal of Economics, 94(2):253-273.

Delli Gatti, D., Desiderio, S., Gaffeo, E., Cirillo, P., and Gallegati, M. (2011). Macroeconomics from the Bottom-up. Springer Milan. 
DeLong, J. and Summers, L. (2012). Fiscal policy in a depressed economy. Booking Papers on Economic Activity, 44(1):233-274.

Dosi, G., Fagiolo, G., Napoletano, M., and Roventini, A. (2013). Income distribution, credit and fiscal policies in an agent-based Keynesian model. Journal of Economic Dynamics 86 Control, 37(8):1598-1625.

Dosi, G., Fagiolo, G., Napoletano, M., Roventini, A., and Treibich, T. (2015). Fiscal and monetary policies in complex evolving economies. Journal of Economic Dynamics and Control, 52:166 - 189.

Dosi, G., Fagiolo, G., and Roventini, A. (2010). Schumpeter meeting keynes: A policy-friendly model of endogenous growth and business cycles. Journal of Economic Dynamics and Control, 34(9):1748-1767.

Erlingsson, E., Teglio, A., Cincotti, S., Stefansson, H., Sturluson, J., and Raberto, M. (2014). Housing market bubbles and business cycles in an agent-based credit economy. Economics: The Open-Access, OpenAssessment E-Journal, 8(2014-8).

Fabiani, S., Druant, M., Hernando, I., Kwapil, C., Landau, B., Loupias, C., Martins, F., Math, T., Sabbatini, R., Stahl, H., and Stokman, A. (2006). What firms' surveys tell us about price-setting behavior in the euro area. International Journal of Central Banking, 2(3).

Fazzari, S. M., Ferri, P., and Greenberg, E. (2008). Cash flow, investment, and keynes-minsky cycles. Journal of Economic Behavior $\& 5$ Organization, $65(3-4): 555-572$.

Ferraresi, T., Roventini, A., and Fagiolo, G. (2014). Fiscal policies and credit regimes: a TVAR approach. Journal of Applied Econometrics, (2013/03).

Fontana, G. (2003). Post keynesian approaches to endogenous money: a time framework explanation. Review of Political Economy, 15(3):291-314.

Gabbi, G., Iori, G., Jafarey, S., and Porter, J. (2015). Financial regulations and bank credit to the real economy. Journal of Economic Dynamics and Control, 50:117 - 143 .

Graham, J. and Harvey, C. (2001). The theory and practice of corporate finance: evidence from the field. Journal of Financial Economics, 60(23):187-243.

Graham, J. and Harvey, C. (2002). How do CFOs make capital budgeting and capital structure decisions? Journal of Applied Corporate Finance, 15(1):823.

Guajardo, J., Leigh, D., and Pescatori, A. (2011). Expansionary austerity: New international evidence. IMF Working Papers 11/158, International Monetary Fund.

Gualdi, S., Tarzia, M., Zamponi, F., and Bouchaud, J. (2015). Tipping points in macroeconomic agent-based models. Journal of Economic Dynamics and Control, 50:29 - 61 .

Hillier, F. and Lieberman, G. (1986). Introduction To Operations Research, 4th Ed. McGraw-Hill, San Francisco, CA, USA.

Kahneman, D. and Tversky, A. (1979). Prospect theory: an analysis of decision under risk. Econometrica, 47(2):263-292. 
Kirman, A. (1992). "whom or what does the rapresentative individual represent?". Journal of Economic Perspective, 6(2):117-136.

Klimek, P., Poledna, S., Farmer, D., and Thurner, S. (2015). To bail-out or to bail-in? answers from an agent-based model. Journal of Economic Dynamics and Control, 50:144 - 154.

Koo, C. (2014). The Escape from Balance Sheet Recession and the QE Trap: A Hazardous Road for the World Economy. Wiley.

Koo, R. (2009). The Holy Grail of Macroeconomics: Lessons from Japan Great Recession. John Wiley \& Sons.

Koo, R. (2011). The world in balance sheet recession: causes, cure and politics. Real-world economics review, 58:19-37.

Krugman, P. (2013). How the case for austerity has crumbled.

Lavoie, M. and Godley, W. (2012). Monetary Economics: An Integrated Approach to Credit, Money, Income, Production and Wealth. Palgrave Macmillan, 2nd edition edition.

LeBaron, B. and Tesfatsion, L. (2008). Modeling macroeconomies as openended dynamic systems of interacting agents. American Economics Review, 98(2):246-250.

Lerner, A. P. and Harris, S. E. (1951). Economics of Employment. McGrawHill.

McLeay, M., Radia, A., and Thomas, R. (2014). Money creation in the modern economy. Bank of England Quarterly Bulletin, 54(1):14-27.

Myers, S. and Majluf, N. (1984). Corporate financing and investment decisions when firms have information that investors do not have. Journal of Financial Economics, 13(2):187-221.

Plott, C. R. and Sunder, S. (1982). Efficiency of experimental security markets with insider information: an application of rational-expectations models. $J$ Polit Econ, 90(4):663-698.

Raberto, M., Teglio, A., and Cincotti, S. (2008a). Integrating real and financial markets in an agent-based economic model: an application to monetary policy design. Computational Economics, 32(1):147-162.

Raberto, M., Teglio, A., and Cincotti, S. (2008b). Prospect Theory Behavioral Assumptions in an Artificial Financial Economy, volume 614 of Lecture Notes in Economics and Mathematical Systems, pages 55-66. Springer.

Raberto, M., Teglio, A., and Cincotti, S. (2012). Debt deleveraging and business cycles. an agent-based persperctive. The Open-Access, OpenAssessment E-Journal, 6:2012-27.

Rengs, B. and Wackerle, M. (2014). A computational agent-based simulation of an artificial monetary union for dynamic comparative institutional analysis. In Computational Intelligence for Financial Engineering Economics (CIFEr), 2104 IEEE Conference on, pages 427-434.

Riccetti, L., Russo, A., and Gallegati, M. (2013). Leveraged networkbased financial accelerator. Journal of Economic Dynamics and Control, 37(8):1626-1640.

Saunders, A. and Allen, L. (2010). Credit Risk. Measurement In and Out of 
the Financial Crisis. Wiley.

Taylor, J. B. (1993). Discretion versus policy rule in practice. In CarnegieRochester Conference Series on Public Policy, volume 39, pages 195-214.

Teglio, A., Raberto, M., and Cincotti, S. (2009). Explaining equity excess return by means of an agent-based financial market, volume 631 of Lecture Notes in Economics and Mathematical Systems, chapter 12, pages 145-156. Springer Verlag.

Teglio, A., Raberto, M., and Cincotti, S. (2012). The impact of banks' capital adequacy regulation on the economic system: An agent-based approach. Advances in Complex Systems, 15(supp02):1250040.

Tesfatsion, L. and Judd, K. L. (2006). Handbook of computational economics, vol. 2: Agent based computational economics. (Handbooks in Economics Series, Elsevier).

Wackerle, M., Rengs, B., and Radax, W. (2014). An agent-based model of institutional life-cycles. Games, 5(3):160-187.

Yeh, A., Twaddle, J., and Frith, M. (2005). Basel II: A new capital framework. Technical report, Reserve Bank of New Zealand: Bulletin, vol. 68, no. 3. 


\section{Tables}

\begin{tabular}{ccccc|cccc}
\hline$F C$ & $S G P$ & $U$ & $Q E$ & $F A$ & Tax Rates & Debt/GDP & Deficit/GDP & Bond Yield \\
\hline$\checkmark$ & & & & & $22.22(0.40)$ & $99(3)$ & $1.21(0.44)$ & $8.40(0.27)$ \\
$\checkmark$ & & $\checkmark$ & & & $20.29(0.37)$ & $110(4)$ & $3.23(0.46)$ & $9.33(0.39)$ \\
$\checkmark$ & & $\checkmark$ & $\checkmark$ & & $21.03(0.32)$ & $105(4)$ & $2.11(0.45)$ & $8.42(0.32)$ \\
$\checkmark$ & & $\checkmark$ & $\checkmark$ & $\checkmark$ & $19.64(0.30)$ & $121(7)$ & $4.27(0.58)$ & $9.44(0.46)$ \\
& $\checkmark$ & & & & $20.22(0.34)$ & $117(6)$ & $2.85(0.33)$ & $12.42(0.45)$ \\
& $\checkmark$ & $\checkmark$ & & & $18.74(0.32)$ & $140(8)$ & $5.07(0.41)$ & $15.02(0.74)$ \\
& $\checkmark$ & $\checkmark$ & $\checkmark$ & & $19.48(0.28)$ & $131(7)$ & $3.77(0.39)$ & $13.19(0.54)$ \\
& $\checkmark$ & $\checkmark$ & $\checkmark$ & $\checkmark$ & $18.29(0.30)$ & $163(11)$ & $6.92(0.58)$ & $14.41(0.70)$ \\
\hline
\end{tabular}

Table 6

Fiscal policy and public accounts: yearly statistics (\%)

\begin{tabular}{ccccc|ccc}
\hline$F C$ & $S G P$ & $U$ & $Q E$ & $F A$ & \# Depressions & Duration & Bankruptcy Prob.(\%) \\
\hline$\checkmark$ & & & & & $1.6(0.2)$ & $18.7(1.4)$ & $39.64(5.73)$ \\
$\checkmark$ & & $\checkmark$ & & & $1.2(0.2)$ & $15.4(0.8)$ & $19.86(4.40)$ \\
$\checkmark$ & & $\checkmark$ & $\checkmark$ & & $1.3(0.1)$ & $14.8(0.9)$ & $29.16(5.20)$ \\
$\checkmark$ & & $\checkmark$ & $\checkmark$ & $\checkmark$ & $0.9(0.1)$ & $12.9(0.7)$ & $22.28(4.44)$ \\
& $\checkmark$ & & & & $1.0(0.1)$ & $14.0(1.5)$ & $25.18(4.61)$ \\
& $\checkmark$ & $\checkmark$ & & & $0.9(0.1)$ & $14.0(0.9)$ & $18.32(3.60)$ \\
& $\checkmark$ & $\checkmark$ & $\checkmark$ & & $1.0(0.1)$ & $14.1(1.0)$ & $23.02(5.01)$ \\
& $\checkmark$ & $\checkmark$ & $\checkmark$ & $\checkmark$ & $0.9(0.1)$ & $12.8(0.8)$ & $22.68(5.31)$ \\
\hline
\end{tabular}

Table 7

Crisis analysis. \# depressions is the number of episodes with, at least, two consecutive months where unemployment rate is higher than $10 \%$. Duration is the average number of months that characterize depressions. Bankruptcy prob.(\%) represents firms' bankruptcy probability during depressions. 


\begin{tabular}{ccccc|cccc}
\hline$F C$ & $S G P$ & $U$ & $Q E$ & $F A$ & \# Depression & Duration & Bankruptcy Prob.(\%) & Max Unempl. \\
\hline$\checkmark$ & & & & & $0.8(0.1)$ & $9.5(0.6)$ & $33.78(5.56)$ & $39.57(2.17)$ \\
$\checkmark$ & & $\checkmark$ & & & $0.5(0.1)$ & $8.0(0.6)$ & $15.76(4.10)$ & $33.55(1.75)$ \\
$\checkmark$ & & $\checkmark$ & $\checkmark$ & & $0.4(0.1)$ & $8.8(0.5)$ & $21.30(4.72)$ & $35.11(1.95)$ \\
$\checkmark$ & & $\checkmark$ & $\checkmark$ & $\checkmark$ & $0.3(0.1)$ & $6.9(0.4)$ & $14.12(4.17)$ & $31.13(1.20)$ \\
& $\checkmark$ & & & & $0.5(0.1)$ & $9.4(0.5)$ & $19.98(4.36)$ & $33.69(1.83)$ \\
& $\checkmark$ & $\checkmark$ & & & $0.5(0.1)$ & $8.9(0.6)$ & $11.42(3.04)$ & $29.37(0.91)$ \\
& $\checkmark$ & $\checkmark$ & $\checkmark$ & & $0.5(0.1)$ & $8.2(0.5)$ & $15.00(4.07)$ & $32.10(1.60)$ \\
& $\checkmark$ & $\checkmark$ & $\checkmark$ & $\checkmark$ & $0.3(0.1)$ & $7.0(0.5)$ & $17.02(4.65)$ & $31.87(1.71)$ \\
\hline
\end{tabular}

Table 8

Crisis analysis. \# depressions is the number of episodes with, at least, two consecutive months where unemployment rate is higher than $20 \%$. Duration is the average number of months that characterize depressions. Bankruptcy prob.(\%) represents firms' bankruptcy probability during depressions. Max unemployment respresents the unemloyment rate peak for each scenario.

\begin{tabular}{ccccc|cccc}
\hline$F C$ & $S G P$ & $U$ & $Q E$ & $F A$ & Money Wage & Price & Real Wage & CB Rate \\
\hline$\checkmark$ & & & & & $6.47(0.21)$ & $4.01(0.20)$ & $1.94(0.12)$ & $3.48(0.15)$ \\
$\checkmark$ & & $\checkmark$ & & & $6.90(0.17)$ & $4.44(0.19)$ & $2.17(0.09)$ & $3.71(0.16)$ \\
$\checkmark$ & & $\checkmark$ & $\checkmark$ & & $6.81(0.15)$ & $4.26(0.20)$ & $2.18(0.10)$ & $3.73(0.14)$ \\
$\checkmark$ & & $\checkmark$ & $\checkmark$ & $\checkmark$ & $7.24(0.10)$ & $4.63(0.16)$ & $2.35(0.11)$ & $4.03(0.13)$ \\
& \multirow{2}{*}{$\checkmark$} & & & & $7.14(0.16)$ & $4.64(0.19)$ & $2.17(0.12)$ & $3.72(0.12)$ \\
& $\checkmark$ & $\checkmark$ & & & $7.28(0.14)$ & $4.79(0.15)$ & $2.26(0.12)$ & $3.96(0.13)$ \\
& $\checkmark$ & $\checkmark$ & $\checkmark$ & & $7.29(0.12)$ & $4.95(0.17)$ & $2.02(0.10)$ & $3.93(0.11)$ \\
& $\checkmark$ & $\checkmark$ & $\checkmark$ & $\checkmark$ & $7.35(0.11)$ & $4.68(0.16)$ & $2.42(0.11)$ & $4.23(0.13)$ \\
\hline
\end{tabular}

Table 9

Prices: yearly growth rates (\%) and central bank rate (\%) 


\begin{tabular}{ccccc|cccc}
\hline$F C$ & $S G P$ & $U$ & $Q E$ & $F A$ & Consumption & GDP & Unemployment & Capital Stock \\
\hline$\checkmark$ & & & & & $1.71(0.13)$ & $2.19(0.18)$ & $5.57(0.29)$ & $8.43(0.19)$ \\
$\checkmark$ & & $\checkmark$ & & & $2.03(0.10)$ & $2.73(0.15)$ & $4.60(0.20)$ & $8.71(0.16)$ \\
$\checkmark$ & & $\checkmark$ & $\checkmark$ & & $2.04(0.09)$ & $2.63(0.16)$ & $4.64(0.21)$ & $8.66(0.16)$ \\
$\checkmark$ & & $\checkmark$ & $\checkmark$ & $\checkmark$ & $2.08(0.10)$ & $2.86(0.15)$ & $4.06(0.19)$ & $8.85(0.14)$ \\
& $\checkmark$ & & & & $2.12(0.10)$ & $2.83(0.13)$ & $4.33(0.25)$ & $9.07(0.18)$ \\
& $\checkmark$ & $\checkmark$ & & & $2.16(0.08)$ & $2.95(0.10)$ & $3.90(0.18)$ & $9.10(0.17)$ \\
& $\checkmark$ & $\checkmark$ & $\checkmark$ & & $1.95(0.09)$ & $2.75(0.14)$ & $4.30(0.21)$ & $9.06(0.17)$ \\
& $\checkmark$ & $\checkmark$ & $\checkmark$ & $\checkmark$ & $2.11(0.10)$ & $2.88(0.14)$ & $3.99(0.21)$ & $8.88(0.17)$ \\
\hline
\end{tabular}

Table 10

Real variables yearly growth rates (\%)

\begin{tabular}{ccccc|ccc}
\hline$F C$ & $S G P$ & $U$ & $Q E$ & $F A$ & Loans & Deposits & Equity \\
\hline$\checkmark$ & & & & & $5.73(0.38)$ & $4.41(0.43)$ & $4.97(0.08)$ \\
$\checkmark$ & & $\checkmark$ & & & $6.84(0.32)$ & $6.12(0.34)$ & $6.38(0.07)$ \\
$\checkmark$ & & $\checkmark$ & $\checkmark$ & & $6.40(0.33)$ & $5.55(0.36)$ & $5.78(0.07)$ \\
$\checkmark$ & & $\checkmark$ & $\checkmark$ & $\checkmark$ & $7.05(0.21)$ & $6.80(0.22)$ & $6.44(0.04)$ \\
& $\checkmark$ & & & & $7.27(0.31)$ & $6.61(0.37)$ & $7.00(0.06)$ \\
& $\checkmark$ & $\checkmark$ & & & $7.66(0.23)$ & $7.50(0.25)$ & $7.37(0.06)$ \\
& $\checkmark$ & $\checkmark$ & $\checkmark$ & & $7.63(0.27)$ & $7.28(0.25)$ & $7.21(0.06)$ \\
& $\checkmark$ & $\checkmark$ & $\checkmark$ & $\checkmark$ & $7.28(0.24)$ & $7.65(0.23)$ & $6.91(0.06)$ \\
\hline & & & & & & &
\end{tabular}

Table 11

Credit variables yearly growth rates (\%) 


\section{Figures}
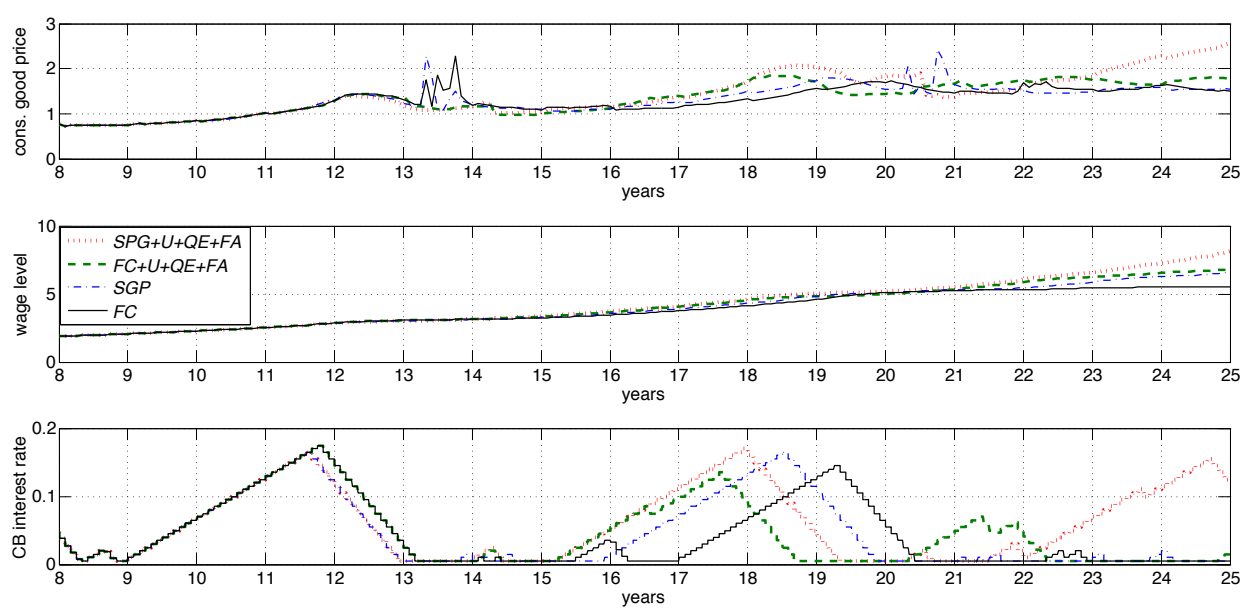

Fig. 1. Monthly consumption good price (Top Panel), wage level (middle Panel) and central bank interest rate (Bottom Panel) for four different fiscal and monetary policy scenarios. 

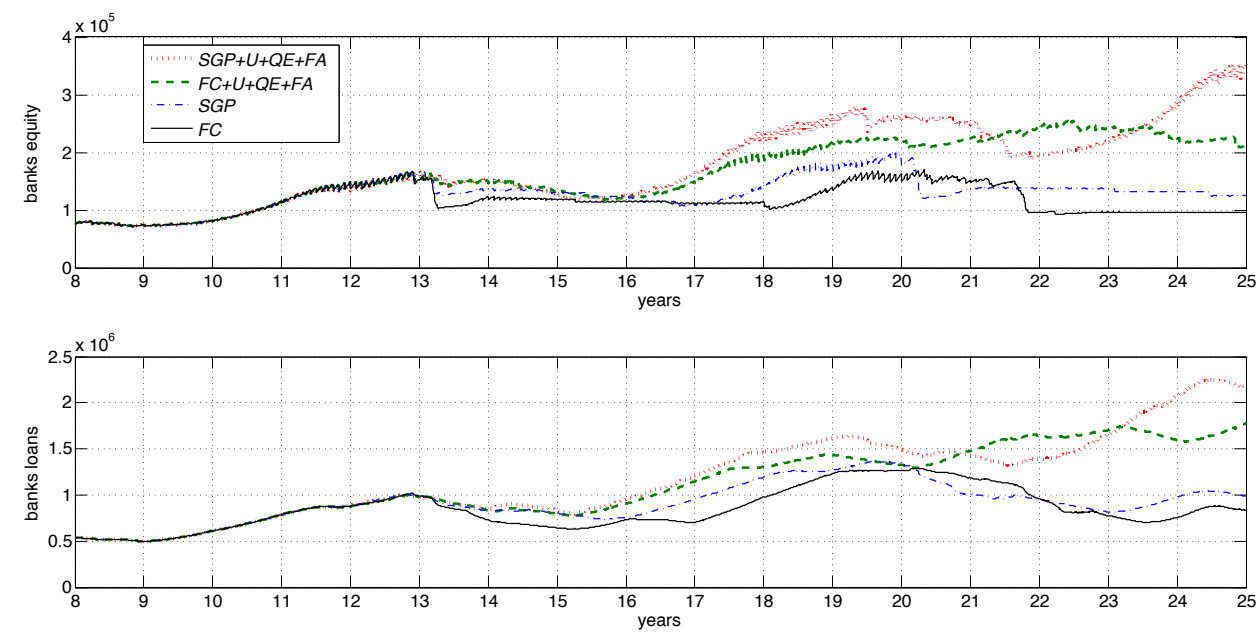

Fig. 2. Monthly banks' equity (Top Panel) and banks' loans (Bottom Panel) for four different fiscal and monetary policy scenarios. 

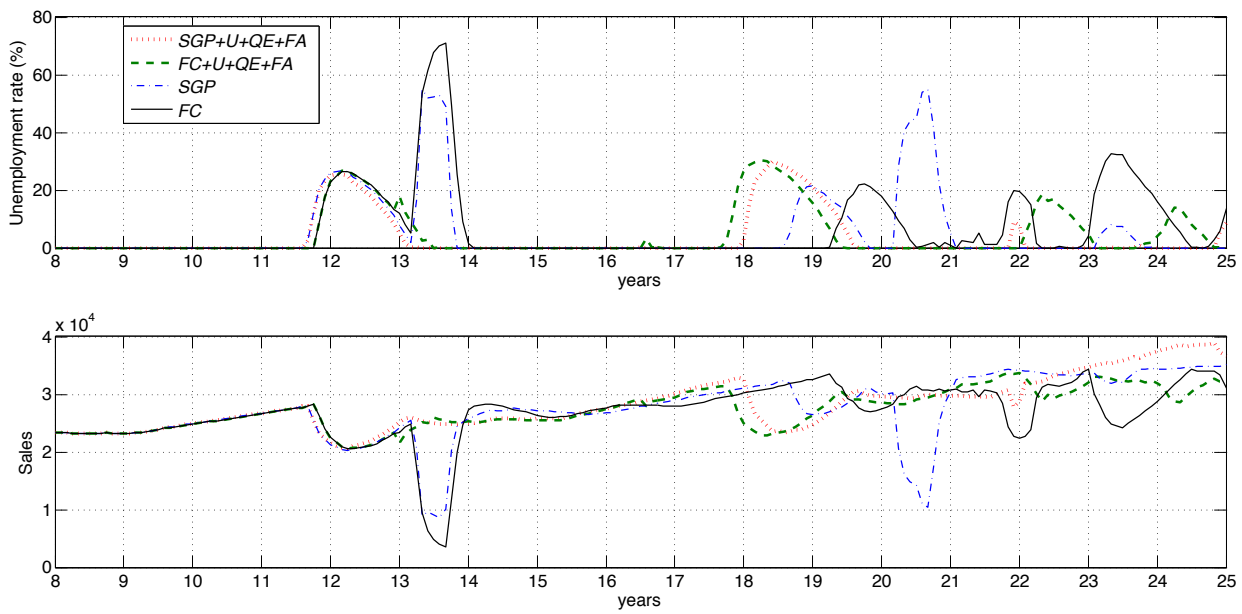

Fig. 3. Monthly unemployment rate (Top Panel) and sales (Bottom Panel) for four different fiscal and monetary policy scenarios. 

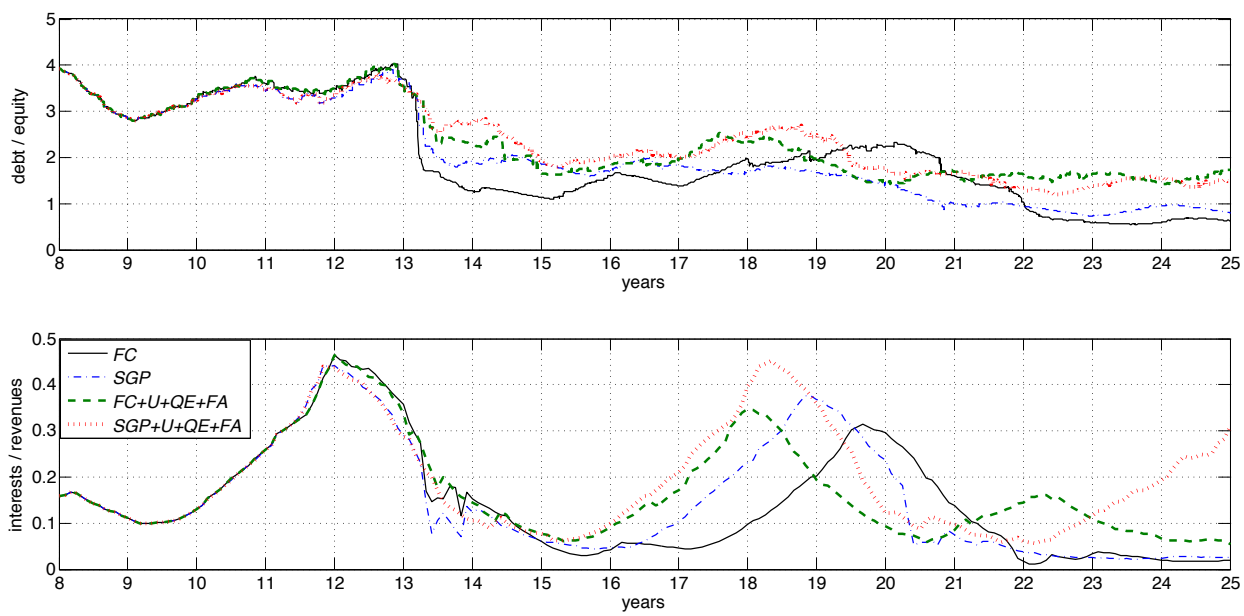

Fig. 4. Firms' monthly debt to equity ratio (Top Panel) and interest to revenues ratio (Bottom Panel) for four different fiscal and monetary policy scenarios. 

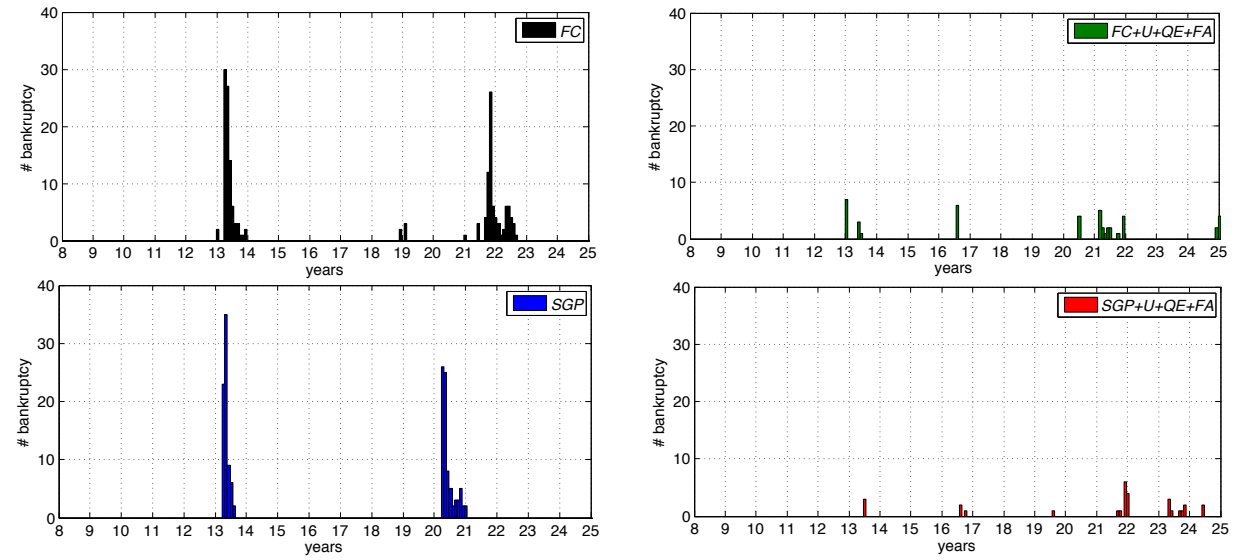

Fig. 5. Monthly number of illiquidity bankruptcies for four different fiscal and monetary policy scenarios. 

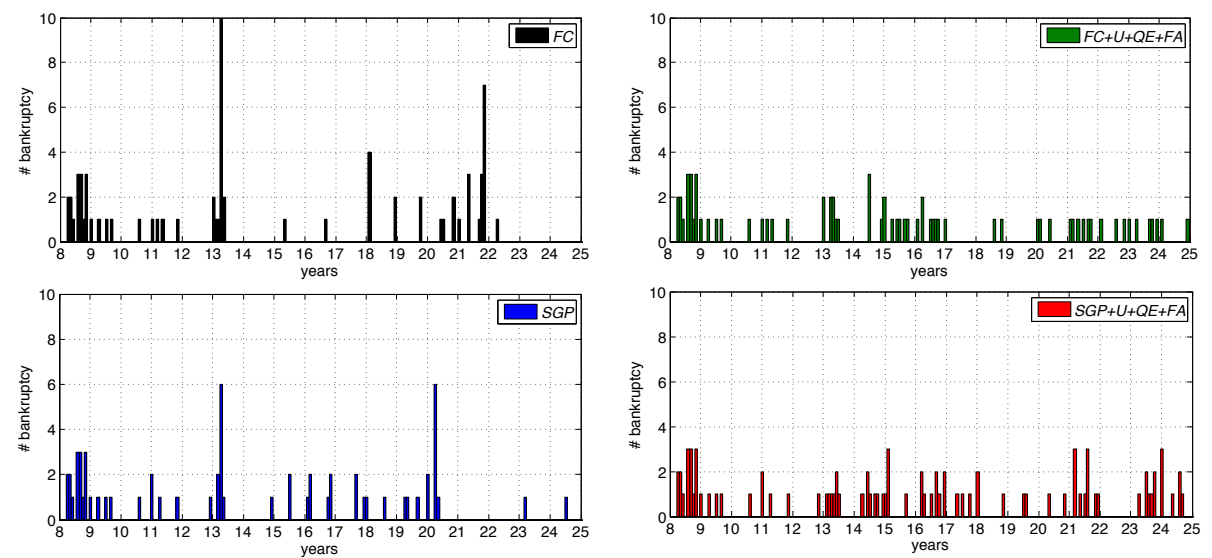

Fig. 6. Monthly number of insolvency bankruptcies for four different fiscal and monetary policy scenarios. 

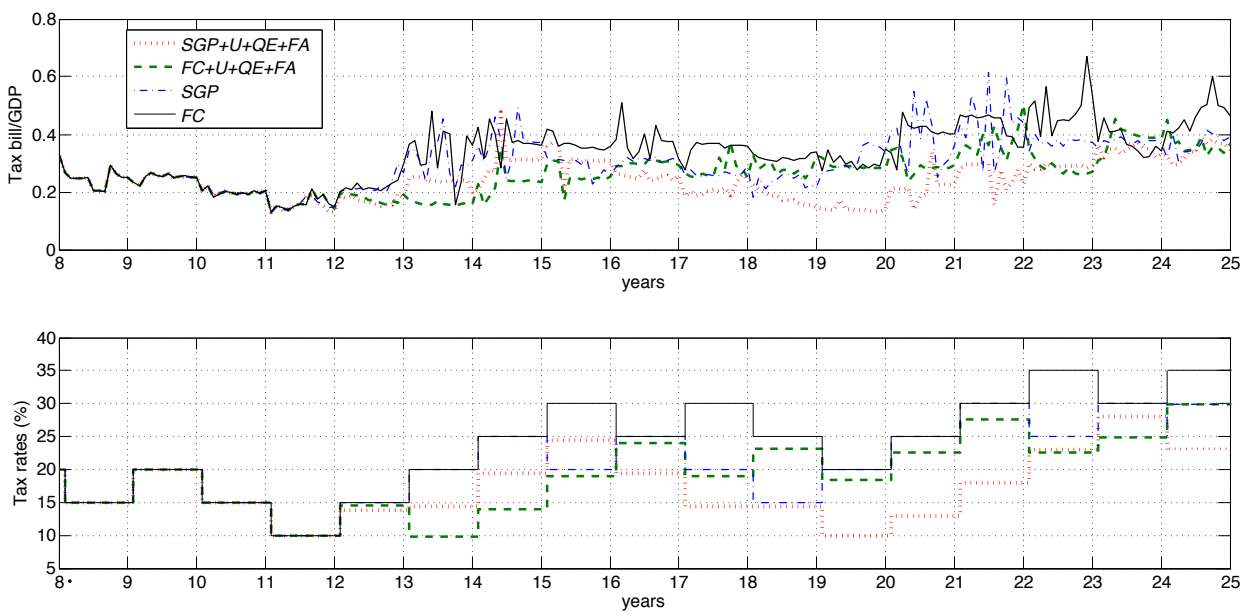

Fig. 7. Monthly tax bill / GDP (Top Panel) and tax rates (Bottom Panel) for four different fiscal and monetary policy scenarios. 

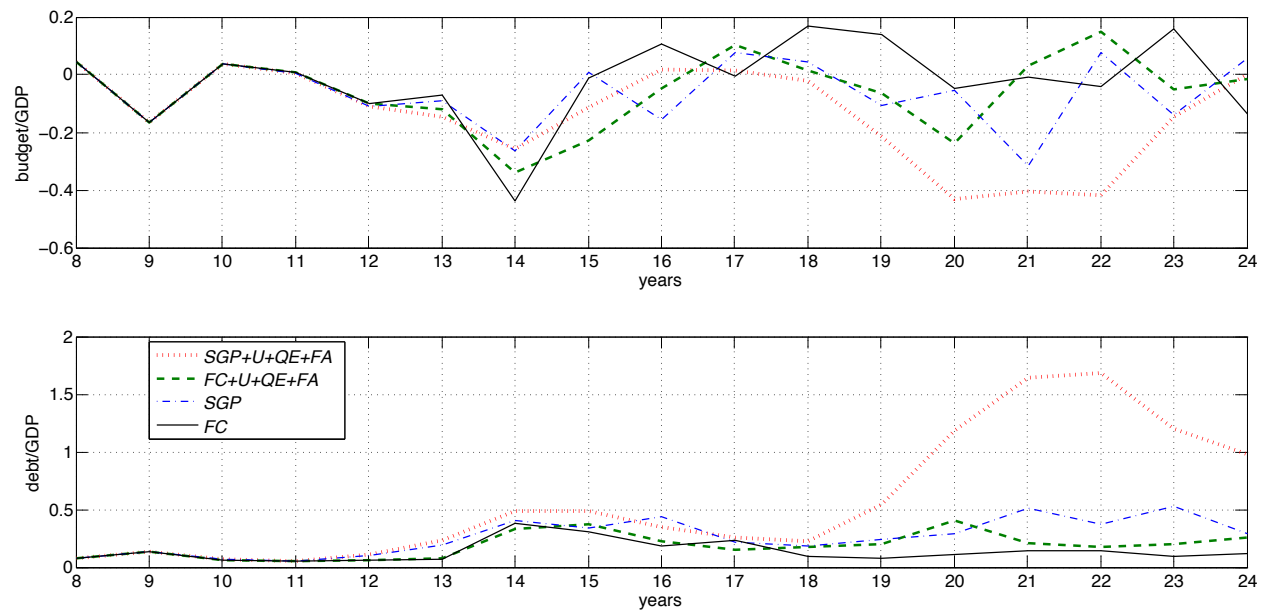

Fig. 8. Monthly budget to GDP ratio (Top Panel) and debt to GDP ratio (Bottom Panel) for four different fiscal and monetary policy scenarios. 


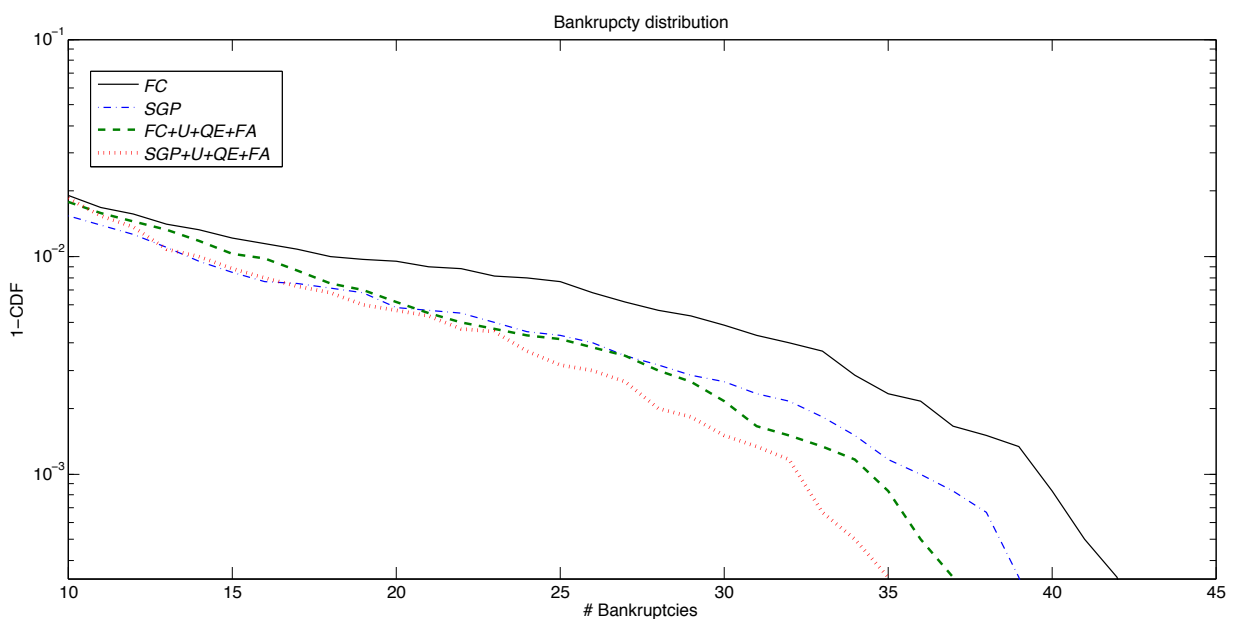

Fig. 9. Inverse cumulative distribution of firms' bankruptcies during a bimester. 